H A R VAR D

The Cost of Property Rights: Establishing Institutions on the Philippine Frontier Under American Rule, 1898-1918

Lakshmi Iyer

Noel Maurer

Working Paper

09-023 


\title{
The Cost of Property Rights: Establishing Institutions on the Philippine Frontier Under American Rule, 1898-1918*
}

\author{
Lakshmi Iyer, Harvard Business School \\ Noel Maurer, Harvard Business School and NBER
}

March 2009

\begin{abstract}
We examine three reforms to property rights introduced by the United States in the Philippines in the early 20th century: the redistribution of large estates to their tenants, the creation of a system of secure land titles, and a homestead program to encourage cultivation of public lands. During the first phase of American occupation (1898-1918), we find that the implementation of these reforms was very slow. As a consequence, tenure insecurity increased over this period, and the distribution of farm sizes remained extremely unequal. We identify two primary causes for the slow progress of reform. The first was the high cost of implementing these programs, together with political constraints which prevented the government from subsidizing land reforms to a greater degree. The second was the reluctance of the government to evict delinquent or informal cultivators, especially on public lands, which reduced the costs of tenure insecurity.
\end{abstract}

\footnotetext{
* We would particularly like to thank Leticia Arroyo Abad, Anne Booth, Diego Comin, Rafael Di Tella, Alan Dye, Jeffrey Frieden, Claudia Goldin, Bishnupriya Gupta, Stephen Haber, Richard Hooley, David Moss, and Jeff Williamson for their excellent comments, advice, and help above and beyond the normal. We would also like to thank participants at the Harvard-Hitotsubashi-Warwick Conference (Venice), Harvard University, Harvard Business School, the Sawyer Seminar on Power and Property Rights (UNC-Chapel Hill), UC Davis and Yale University. Avi Mowshovitz and Kevin Jiang provided superlative research assistance. Any and all errors are, of course, wholly our own.
} 
In 1898, the Philippine Islands passed from Spanish to American sovereignty. Under what President William McKinley called "benevolent assimilation" and the U.S. Army termed the "policy of attraction," Washington imposed a new tax system, provided emergency food aid, transferred tariff revenue to the islands, established a public school system, built roads, and attempted to create an entirely new — and presumably more efficient — system of property rights. ${ }^{1}$ Between its establishment in 1900 and the passage of the Philippine Autonomy Act of 1916 (which turned legislative authority over to the Filipinos), the U.S. administration imposed three major reforms: the purchase and redistribution to their tenants of the extensive estates owned by the Catholic Church (the "friar lands"); the creation of a new and improved land-titling system (the Torrens system) and a land court to adjudicate it; and a homestead act combined with prohibitions on large-scale sales of the archipelago's extensive public lands. The aim was twofold: to end the insecurity of property rights that had characterized Spanish rule, and improve the land distribution in the Philippines.

Yet two decades after the arrival of the Americans, property rights in the Philippines had become unambiguously less secure. The incidence of squatting jumped from 2.4 percent of cultivated area to 7.5 percent. Only 4.5 percent of land parcels had been issued Torrens land titles, and less than 12 percent of public lands had received formal homestead rights. The U.S. did manage to redistribute twothirds of the friar lands by 1918, but 25 percent of the purchasers had fallen behind on their payments for the land they received. The overall level of land inequality, measured by the Gini coefficient, remained at the extremely high value of 0.75 , despite a large increase in the overall area under cultiva-

\footnotetext{
${ }^{1}$ Karen Clay has studied the effect of the transfer of sovereignty from Mexico to the United States on land rights in California. In California, the U.S. passed the California Land Act, which required all possessors of land rights under the previous regime to prove their title before a specialized land commission within two years. The law allowed the owners of rejected (but uncontested) claims to purchase their lands for \$1.25 an acre. Resolution was slow — it typically took 17 years to resolve a claim. See Clay, “California Land,” p. 134. In Hawaii, meanwhile, the new American government did not need to establish a new property rights system in 1898. Nor, in fact, did the organizers of the pro-American coup d'état in 1893. Rather, the Kingdom of Hawaii had already engaged in a substantial property rights reform of its own in 1844-56, during which the traditional land system was converted into fee-simple titles. The government's desire to take advantage of the opportunities provided by sugar cultivation prompted the reform. See La Croix and Roumasset, "Evolution.”
} 
tion. In other words, the Philippines' new American managers, with all the administrative and legal resources of the United States and full sovereignty over the country, not only failed to improve the security of property rights or the distribution of wealth, but appear to have made them worse.

Why did the American territorial government fail to implement these reforms, despite a strong commitment to fostering economic growth and improving conditions in the Philippines? We find evidence of constraints on both the supply-side and the demand-side.

On the supply side, the high cost of providing secure property rights, together with the inability of the government to subsidize the process, proved the major constraint. In order to minimize the fiscal cost, the government set the purchase price for the redistributed friar lands too high for poor Filipino peasants, leading to a high level of delinquency in the required payments. A lack of trained surveyors and technical difficulties of obtaining accurate maps raised the cost of conducting surveys, and therefore the cost of issuing Torrens titles and verifying homestead claims. The insular administration failed to generate enough revenue to subsidize this cost for Filipino farmers; we estimate that it would have cost about $57 \%$ of government revenue to fully subsidize the cost of land titling. There was little room to raise taxes: measured as a percent of GDP, the Philippine tax burden rivaled those in nearby Asian colonies and the United States, and exceeded those in most states of Latin America. Nor could Washington have easily subsidized the cost: U.S. defense expenditures in the islands were already quite high, and domestic opposition to imperialism meant that it would be difficult to raise them further.

On the demand-side, the relatively low levels of property crime, an abundance of newly-opened frontier land and the political unwillingness of the government to evict squatters on public land reduced the cost of informality for Filipino peasants. Further, our data show no correlation between the possession of land titles and the progress of irrigation or access to credit, in part because these factors 
were publicly subsidized and provided regardless of title. ${ }^{2}$ Smallholders therefore had little incentive to pay the costs associated with formal landownership. In effect, one part of American development strategy undercut the other.

Several developing nations have undertaken, or are currently undertaking, property rights reforms similar to those the Americans tried to implement in the Philippines. For instance, Vietnam, Thailand and Indonesia have all undertaken land titling programs, India has legislated several land reform measures designed to improve the status of tenants, and many Eastern European countries have initiated extensive land redistributions. ${ }^{3}$ Our research suggests that transforming property rights institutions requires the commitment of significant resources, and making sure that people have incentives to formalize their rights. We compare the Philippine experience with later land reforms in Korea and Taiwan, both of which were overseen by the U.S., and are generally regarded to be successes. In both of these later cases, de facto expropriation of large landlords enabled the government to offer redistributed land to peasants at a lower price, and the U.S. also committed resources specifically for the administrative costs of undertaking land reforms.

\section{THE PHILIPPINES UNDER U.S. SOVEREIGNTY}

Official U.S. sovereignty lasted 48 years from 1898 to 1946 (with a brief interregnum in 1942-45). The legacy of Spanish rule and the circumstances of the annexation shaped American policy in the islands.

\footnotetext{
2 U.S. policy in California after the U.S. annexed the territory from Mexico in 1848, as in the Philippines, resulted in a great deal of squatting. Unlike the Philippines, however, Karen Clay found that squatting in California in 1850-60 resulted in both increases in violence and decreases in agricultural productivity. See Clay, “Uncertain Property Rights.” Lee Alston, Gary Libecap, and Bernardo Mueller found something similar in their studies of the Brazilian frontier: increases in squatting were associated with later increases in violence. See Alston, Libecap, and Mueller, "Property Rights."

3 Vietnam issued nearly 11 million land titles to rural households in the 1990s (Do and Iyer, "Land Titling”), Thailand has distributed 8.7 million land titles since the early 1980s and Indonesia issued 1.87 million titles between 1996 and 2000 (SMERU, "Impact Evaluation"). Peru distributed 1.2 million titles to squatters in several cities (Field, "Entitled to Work.”) Besley and Burgess, "Land Reform," analyzed land reforms in India, and find that greater tenant rights leads to substantial reductions in poverty, but no significant increase in output.
} 
“Four Centuries in a Convent”: Spanish Colonial Rule 1565-1898

The first European to arrive in the Philippines was the Portuguese explorer Ferdinand Magellan in 1521. The Philippines came under formal colonial rule in 1565, when Spain’s force defeated the king of Cebu. Spanish rule brought Catholicism to the islands, though substantial Muslim populations remained in Mindanao and the Sulu Archipelago. A combination of the disease environment and a lack of economic opportunities, however, dissuaded Spaniards from moving to the islands in any substantial numbers. In addition, a series of early abuses led the Crown to ban Spaniards (save the clergy) from entering native villages for purposes other than tax collection. With Spanish merchants, settlers, and bureaucrats thin on the ground, the monastic orders of the Dominicans, the Franciscans, the Augustinians, and the Augustinian Recollects (Recoletos) became the de facto administrators of the Philippines. $^{4}$

In most areas, the local friar (in his role of parish priest) was the sole representative of Spanish rule, as well as the only educated person with knowledge of both Spanish and the native language. In his secular capacity, the parish priest inspected schools, administered labor drafts, oversaw elections to municipal offices and the police force, and signed off on the municipal budget. He was the president of the health board, the president of the prison board and the chief advisor for the municipal council. Eventually even tax collection devolved to the friars, who took over responsibility for levying and collecting head taxes. ${ }^{5}$

Over time, the fraternal orders became the largest landowners on the islands. They acquired land through purchase, legal battles, ecclesiastical privileges, and, at times, outright usurpation. To their credit, the friars undertook irrigation projects, and introduced cash crops such as sugarcane, tobacco and coffee to the lands under their control. Other innovations were less savory. The friars regularly

\footnotetext{
${ }^{4}$ Reports of the (Taft) Philippine Commission, p. 23. The Jesuits, Capuchins, Benedictines and the Paulists had a much smaller presence on the islands. By 1903, there were 746 regular parishes, 105 mission parishes and 116 missions.

5 Reports of the (Taft) Philippine Commission, pp. 25-26, based on conversation with the provincial of the Franciscan order. The head tax was called the "cédula," after the identity document that recorded whether it had been paid. The head tax could also be paid in kind, with fifteen days of labor to the Crown. See Vicente Pilapil, “Friar-Problem,” p. 132.
} 
used public labor drafts for private purposes. High fees for baptisms, weddings, funerals and other sacraments further increased tensions with the local population. Another major grievance against the friars was the barriers raised to the advancement of Filipino clergy — often because the friars reserved clerical positions for their own illegitimate children. ${ }^{6}$

Friar land usurpations produced major revolts in 1743, 1872, and 1896. The Cavite uprising of 1872, in particular, galvanized organized resistance against the "friarocracy" and set the stage for a far more serious rebellion. In late 1896, armed rebellion broke out in several provinces around Manila, with the primary goal of expelling the friars. ${ }^{7}$ After over a year of fighting, the rebels surrendered in December 1897, and their leader Emilio Aguinaldo was exiled to Hong Kong.

\section{American Annexation}

The Spanish-American War broke out over Cuba, not the Philippines. In April 1898, the U.S. formally declared war on Spain, and the U.S. Congress authorized President McKinley to "to use the entire land and naval forces of the United States” in order to secure Cuban independence. Neither the U.S. declaration of war nor McKinley’s address to Congress made any mention of the Philippines.

After the declaration of war, the Navy Department in Washington, D.C., sent the Asiatic Squadron (which was stationed in Hong Kong at the time) the following terse order: "Proceed at once to the Philippine Islands. Commence operations at once, particularly against the Spanish fleet. You must capture vessels or destroy. Use utmost endeavors.”9 On May 1st, Admiral George Dewey sailed into Manila Bay and destroyed the Spanish fleet. Lacking instructions to the contrary, Dewey supplied

\footnotetext{
${ }^{6}$ LeRoy, Philippine Life, p. 664, 666.

${ }^{7}$ An 1896 Tagalog circular set out the rebellion's eight aims, in order: (1) The expulsion of the friars and the restitution of their lands; (2) The recognition of Filipino priests in filling the subsequent clerical vacancies; (3) Religious toleration; (4) Equality of Filipinos and Spaniards before the law; (5) Freedom of the press; (6) Guaranteed representation in Madrid; (7) Home rule; (8) The abolition of deportation as a punishment. See Report of the (Schurman) Philippine Commission, part 4, chapter 2, "Governmental Reforms Desired by Filipinos." On November 1, 1897, remaining rebels under Emilio Aguinaldo declared independence in the town of Biak-na-Bato, but surrendered to Spanish troops less than two months later.

8 Presidential Messages and State Papers, Vol. VIII, pp. 2967-69.

${ }^{9}$ Annual Reports of the Navy Department for the Year 1898.
} 
arms to the Philippine guerrillas operating in nearby Cavite and sent a cruiser to fetch Aguinaldo from Hong Kong.

Washington, however, soon ordered Dewey to avoid "political alliances with the insurgents."10 The Philippines had not figured into the American decision to go to war, and McKinley and his cabinet had no pre-existing policy for the archipelago. The Navy argued that the U.S. — dependent at the time on British goodwill — needed a naval base near China in order to defend its interests. The Navy also feared, however, that a base in Manila or Subic Bay would be indefensible without control of Luzon, since it doubted Aguinaldo’s ability to establish a stable government.

The Treaty of Paris, signed on December $10^{\text {th }}, 1898$, transferred Cuba, Guam, the Philippines, and Puerto Rico to the United States. After ten days of dithering, President McKinley declared that U.S. policy in the Philippines was one of "benevolent assimilation, substituting the mild sway of justice and right for arbitrary rule."11 Unlike Cuba, which was promised a rapid transition to independence, the U.S. made no intimation that it would be leaving the Philippines any time soon.

Aguinaldo and the other Philippine rebel leaders violently opposed McKinley’s decision. They established a government at Malolos in 1899 and launched an armed insurgency against the Americans. The Philippine War became the signature issue of the 1900 presidential elections, with the Democrats declaring their opposition and the Republicans supporting the war. (The Philippine insurgents paid close attention to American politics and designed their strategy around the election.) ${ }^{12}$ When the Democratic candidate, Williams Jennings Bryan, lost the 1900 election to Theodore Roosevelt, insurgent morale collapsed, and surrenders multiplied. Aguinaldo accepted an amnesty in March 1901, and subsequently called on his followers to accept U.S. administration. In April 1902, with the surrender of General Miguel Malvar, the U.S. government pronounced the conflict over, although

\footnotetext{
10 Kramer, Blood of Government, p. 94.

11 Kramer, Blood of Government, p. 110.

12 For more detail, see Gates, “Philippine Guerrillas,” pp. 51-64. Iyengar and Monten, “Emboldenment,” find a similar result for the Iraqi insurgency.
} 
sporadic violence continued in outlying areas. Aguinaldo and other prominent rebel leaders received large tracts of land and, later, political offices.

\section{"Fifty Years of Hollywood": The Political Economy of Attraction}

The desire to avoid future insurgencies, as well as Democratic opposition to annexation, led the U.S. to adopt a "policy of attraction" in the Philippines. This included the establishment of a public school system staffed initially by 1500 American teachers, irrigation works, a road program, railroad expansion, the transfer of U.S. tariff revenue to the island until 1909 and free trade thereafter, and a gradual process of "Filipinizing” the local administration that began in 1907. This process culminated with the Philippine Autonomy Act of 1916, which transferred legislative authority to an elected legislature (with limited adult suffrage), with the U.S. Governor-General retaining veto power. ${ }^{13}$

In addition to large-scale investments in education and infrastructure, U.S. policy insured that the Philippines avoided famine. In 1902, when rinderpest wiped out nearly of the country's carabao bulls (the main draught animals used for plowing) and locusts attacked the remaining rice crop, Congress authorized \$3 million in food aid which was used to purchase Vietnamese rice at $4.8 \nsubseteq$ per kilo and sell it to the public at 1.8థ. In 1912, the American government reacted to a drought and the failure of the rice harvest by setting a price ceiling of 5.3థ per kilo and importing rice (at a cost of $7.4 \$$ per kilo) whenever the market price went over that level. ${ }^{14}$ When prices spiked at the end of 1918, the insular government set intervention prices at 5.5 $\$$ in Manila, 4.8థ in Cebu, and 5.1థ in Iloilo, at a cost to the government of $7.9 థ$ per kilo. ${ }^{15}$

\footnotetext{
13 The official government policy was usually called “benevolent assimilation.” The phrase "policy of attraction” was first used by revolutionaries opposed to U.S. occupation; the phrase appears to have originated in a telegram from the U.S. secretaries of war and interior to Emilio Aguinaldo (Philippine Insurgent Records, 1896-1901, National Archives, Washington, D.C., no. 849).

141912 Report of the Philippine Commission, pp. 40-42.

151919 War Department Annual Report, Vol. 3, pp. 205-06. American policies were not completely successful at limiting price increases. Market prices averaged 6.7థ during 1918.
} 
Uniquely among colonial powers, the U.S. government restricted its own citizens from investing in its new possession. The reason was strong domestic opposition to the annexation. Opponents chiefly Democrats — wanted to prevent the emergence of domestic groups with a vested interest in the retention of the Philippines. In order to get the Philippine Organic Act of 1902 past these opponents, President Roosevelt had to agree to clauses which restricted American corporations from owning more than 1024 hectares (2500 acres) of land, prevented the national banking system from extending to the islands, and restricted the ability of the insular government to grant mining claims or other franchises. These restrictions served to insure that the U.S. administration was not subject to capture by private American economic interests.

In the absence of domestic interests in favor of retention, the policy of attraction served a double purpose. First, it reduced Filipino support for severing ties with the United States. In 1916, Manuel Quezon, one of two Philippine nonvoting representatives in Congress, declared that he opposed independence unless the Philippines could be sure to retain a defense guarantee, access to the U.S. market, and other things in the "national interest." Similarly, the head of the Philippine legislature, Sergio Osmeña, worried about rebellion if an independence bill passed, while a prominent Filipino legislator drafted a bill rejecting independence if the U.S. failed to retain defense and trade links. ${ }^{16}$

Second, the policy of attraction served to undercut American opponents of the occupation. Its designers calculated that as long as American policy appeared to be benefitting the Filipino population, it would be increasingly difficult for anti-imperialists to assemble a winning Congressional coalition. For instance, 28 Democrats (26 of whom were from largely Catholic urban constituencies) defected to the Republicans to defeat a 1916 independence bill by seven votes. The defectors did not want to appear to be abandoning their constituents' co-religionists. ${ }^{17}$ Of course, the policy of attrac-

\footnotetext{
16 Peter Stanley, A Nation in the Making, p. 223. 15 years later, in 1932, Quezon and Osmeña privately asked a rather surprised President Hoover to veto an independence bill that they had publicly supported. Hoover, Memoirs, vol. II, p. 361.

17 Peter Stanley, A Nation in the Making, p. 223.
} 
tion would only be politically sustainable inasmuch as the Philippines did not impose a large fiscal cost on American taxpayers.

The historical circumstances of Philippine annexation therefore led to a "benevolent" colonial administration with a long-term time horizon, relative immunity from capture by metropolitan economic interest groups, and the well-being of the population as its top priority. This combination was, to say the least, unusual in the history of imperial rule. ${ }^{18}$

\section{PROPERTY RIGHTS REFORMS}

\section{Land to the Tiller: The Friar Lands Policy}

In 1900 the U.S. sent the Second Philippine Commission, headed by William Howard Taft to assess the situation. ${ }^{19}$ The Taft Commission arrived with full legislative powers and a mandate to establish local government, develop a career-oriented civil service, implement tax measures and pass needed laws. The most immediately pressing task of the Commission, however, was to resolve the “burning political question, discussion of which strongly agitates the people of the Philippines,” of whether the friars should return to the parishes they occupied before the revolution. During the 1896-97 and 1899-1901 upheavals, 40 priests had been killed and 403 imprisoned. Of the 1124 priests present in 1898, only 472 remained in 1903, almost all of them in Manila. ${ }^{20}$

After conducting detailed interviews with the friars, local elites and American military officers, Taft became "convinced that a return of the friars to their parishes will lead to lawless violence and

\footnotetext{
18 Kris Mitchener and Marc Weidenmeir have argued that a series of 1904-07 American interventions in the Caribbean basin produced "public goods" in the sense of reducing borrowing costs for Circum-Caribbean countries and contributing to interstate peace in Central America. Álfaro and Maurer have made similar arguments about the enitre 1904-29 period. Both papers, however, also argue that American interventions in the Caribbean were entirely self-interested and in no way motivated by "benevolence." See Mitchener and Weidenmeir, "Empire,” and Álfaro, Maurer, and Ahmed, "Gunboats.”

19 William Howard Taft was a prominent federal judge who later served as President (1909-13) and Chief Justice (1921-30) of the United States.

20 Reports of the (Taft) Philippine Commission, p 23.
} 
murder, and the people will charge the course taken to the American government, thus turning against it the resentment felt towards the friars."21

Given that the friars were not to go back to their parishes, what was to be done with their lands? Here the Taft Commission had to keep in mind the principle of just compensation and the provisions of the Treaty of Paris, which promised to protect the property rights of the Spanish, specifically including “ecclesiastical bodies."22 Taft concluded that the best solution would be for the insular government to "buy these large haciendas of the friars and sell them out in small holdings to the present tenants."23

Violating the provisions of the Treaty of Paris would have posed three serious problems for the United States. First, it would have destroyed the nation's international reputation, making cooperation with other governments in the future far more difficult. Second, it would have opened the U.S. government up to domestic litigation, since international treaties automatically become part of domestic law. (In fact, the friars sued the U.S. for greater compensation under the treaty.) Third, and perhaps most seriously, Catholics formed a large domestic voting bloc, which would have reacted very negatively to the illegal seizure of Church property by the U.S. federal government. As we shall see, the high price paid to the friars for these lands proved to be a major bottleneck in their redistribution to the peasants.

Protracted negotiations with the friars over the sale of these lands ensued. Most of the disagreement centered on valuation. The friars wanted full compensation for all improvements made on their

\footnotetext{
21 Reports of the (Taft) Philippine Commission, p 31. The danger faced by the friars if they went back was summarized pithily by the grandson of a Franciscan friar: "All the friars have to do is to go back to their parishes and sleep one night, and the chances are that they would never awaken.”

22 Article VIII of the Treaty of Paris reads: "In conformity with the provisions of Articles I, II, and III of this treaty, Spain relinquishes in Cuba, and cedes in Porto Rico and other islands in the West Indies, in the island of Guam, and in the Philippine Archipelago, all the buildings, wharves, barracks, forts, structures, public highways and other immovable property which, in conformity with law, belong to the public domain, and as such belong to the Crown of Spain. And it is hereby declared that the relinquishment or cession, as the case may be, to which the preceding paragraph refers, can not in any respect impair the property or rights which by law belong to the peaceful possession of property of all kinds, of provinces, municipalities, public or private establishments, ecclesiastical or civic bodies, or any other associations having legal capacity to acquire and possess property in the aforesaid territories renounced or ceded, or of private individuals, of whatsoever nationality such individuals may be.”

23 Reports of the (Taft) Philippine Commission, p 32.
} 
estates, and the Dominicans went so far as to sell the sugar mills and the railroads on their haciendas to third parties. On December 22, 1903, the United States agreed to buy 170,916 hectares $(403,000$ acres) for a price of just above US\$6 million. ${ }^{24}$ After some more negotiation, and a Supreme Court decision mandating that the U.S. government would have to compensate the friars for improvements, the ultimate price paid for the friar lands came to US\$6.9 million. ${ }^{25}$ The insular government issued special bonds to raise this money. The bonds offered a $4 \%$ interest rate and were payable between ten and thirty years, at the option of the government. They were not officially backed by the U.S. Treasury, but by the revenues of the government of the Philippine Islands.

Did the U.S. pay too much for the friar lands? Governor Taft initially estimated the annual income from the friar lands at not more than $\$ 225,000$, implying that the sale price represented more than 26 times income. Taft justified the price as follows: "It is to be noted, however, that the insular government has not entered upon the purchase of these lands with a view to a profitable investment, but that it is knowingly paying a considerable sum of money merely for the purpose of ridding the administration of the government in the islands of an issue dangerous to the peace and prosperity of the people of the islands. ${ }^{, 26}$ In other words, the U.S. was willing to pay a premium to get the friars out of the Philippines. In this, they largely succeeded: by the end of 1904, the remaining Spanish bishops in the Philippines had been replaced by Americans.

The government gave current occupants of friar lands the first preference to lease, purchase or acquire their holdings. Since the law precluded sales larger than 16 hectares, this process involved surveying the land, subdividing it into parcels and determining an appropriate sale price for each par-

\footnotetext{
24 In 1903, one U.S. dollar was worth two pesos.

25 Corpuz, An Economic History, pp. 267-69.

${ }^{26}$ Reports of the (Taft) Philippine Commission, p 44.

27 Dean Worcester, the Secretary of the Interior confirmed this view: “The price originally paid for the friar lands was high, and most of us, at the outset, believed that the transaction would involve the Government in considerable financial loss, which it seemed best to bear in view of the compensating benefits to be gained.” (Philippine Government, The Friar-Land Inquiry, p. 129).
} 
cel. ${ }^{28}$ This process took a number of years, and was not completed before 1908 for any estate. ${ }^{29}$ The current occupant of the land was then given the option to purchase it. The government chose not to subsidize the administrative costs of this program, with the result that the purchaser had to pay for the cost of the surveys and any administrative expenses including attorney's and registration fees. Furthermore, in order to recoup the interest expense on the bonds, the government raised the price of the lands as time went on. For instance, the original purchase price of the Guiguinto estate was 155,567 pesos, but its final selling price was determined in June 1908 to be 200,276 pesos, an increase of nearly 28 percent. ${ }^{30}$ While this process was ongoing, the current tenants of the land continued to pay rent to the government.

\section{Order from Chaos: The Torrens System of Land Titling}

Taft also reformed the laws governing land titles. "A very large percentage of the lands are occupied and claimed by individuals without any record title whatever," observed the Taft Commission. Many of the titles had been destroyed during the wars and political instability of the preceding years. Despite the lack of formal record title, most landholders had a "title of possession.” That is to say, their neighbors conceded that they had a right to the land. However, the government feared that the disadvantages of this informal system would grow over time, inhibiting investment, preventing the development of a credit system, and potentially leading to violence.

In order to improve the chaotic state of land rights, the Commission passed the Land Registration Act of 1903, which provided for the Torrens system of land registration in the Philippines. Under the new system, the government set up a centralized land registry. Any document (such as a sales registry or a mortgage) recorded at the central registry would be considered automatically effective, legally

\footnotetext{
28 Governor Taft strongly felt that this low limit would discourage large-scale plantation agriculture, and recommended several times that the limit be raised considerably. In fact, this provision was violated in many instances, with some American officials and local elites managing to acquire large estates. For instance, Emilio Aguinaldo received 1055 hectares from the Imus estate.

29 Escalante, Friar Lands, Table 14, p 129.

30 Escalante, Friar Lands, Table 15, p 130.
} 
incontestable, fully transparent, and completely transferable. Since a Torrens title would be incontestable, registration required an investigation of the title and all possible liens on the property in order to work. During that investigation, it was quite possible for a registrant to discover that they did not, in fact, own their land. The Land Registration Act therefore created an "assurance fund" for landowners to draw upon in case they lost their land by reason of a title investigation. In addition, the Land Registration Act created a Court of Land Registration with nationwide jurisdiction to administer the new system.

The new system, however, did not replace the old system. Landowners with a title of possession retained their rights, but remained vulnerable to legal disputes unless they could document a "chain of ownership” back to the royal titles originally issued by the Spanish Crown.

\section{Forty Acres and a Carabao: The Public Lands Policy}

The Treaty of Paris granted the U.S. government title to the Philippines' expansive vacant lands. An estimated 8.4 million hectares of agricultural land and twice that amount of forest lands were estimated to be in the public domain at the beginning of U.S. occupation. ${ }^{31}$ The Philippines of 1903 more resembled a classic frontier economy than today's overcrowded archipelago. The country's overall population density was only 66 people per square mile in 1903, much lower than other Asian countries at the time; in fact, the Philippines’ 1903 population density was 13 percent lower than that of the state of Indiana in 1900. (See Table 1).

\section{TABLE 1 AROUND HERE}

The U.S. policy was to open the public lands to settlement, following the model of the U.S. Homestead Act, adjusted for Philippine conditions. Under the Philippine Homestead Act, potential homesteaders could apply for a plot of land up to a maximum of 16 hectares (40 acres). The government

311906 Primer on the Public Land Laws, p.3. 
would survey the plot, and if approved, the family would receive a "non-patented approval.” After five years' residence, the family would receive a title.

This was a significant difference from the earlier Spanish policy of attempting to control the expansion of the islands' cultivated area through draconian anti-squatting laws. Peasants who could not produce identification demonstrating that they had paid the head tax in the locality were subject to expulsion by colonial soldiers. ${ }^{32}$ There were two main reasons for this. First, Madrid recognized that the public lands were a valuable asset, and it wanted to maximize its returns from selling them off. Valuable tracts were sold off throughout the $19^{\text {th }}$ Century, and in 1894 , a new law was passed that allowed private individuals to place claims before provincial governments. Second, the low population density meant that the settled population did not begin to significantly encroach upon the royal lands until relatively late in the colonial period. The first reports that "uncultivated [private] lands diminish daily” in the area around Manila didn’t appear until 1845. Only in the late 1870s did colonial officials report that village commons were starting to disappear. ${ }^{33}$ The 1884 decree finally made provision for this factor by ruling that those who could prove that they had occupied public land for twenty years (and actively cultivated it for the past three) would receive possession. ${ }^{34}$

Despite the draconian nature of Spanish law, many families lived on public land without title. In order to deal with these families, the Philippine Homestead Act granted the residents of public lands several years to produce documents or witnesses that could attest that they had occupied their plot before 1898. Once verified, the Commission would grant the family a “free patent.”

\footnotetext{
32 Corpuz, An Economic History, p. 155. In fact, the colonial government was so reluctant to allow native Filipinos to move freely that in 1850 it authorized plantations facing labor shortages to import Chinese workers rather than permit them to hire Filipinos. In 1884 the Spanish reformed the law to allow Filipinos to leave their home villages, but only with the permission of the local parish priest, who stood to lose stipends should he lose his parishioners.

33 Corpuz, An Economic History, p. 117, 148.

34 61st Congress, Administration of Philippine Lands, pp. 708-09 and 1024.
} 
THE PROGRESS OF PROPERTY RIGHTS, 1903-1918

The implementation of each of the property rights reforms was flawed, and very little progress was made in the first two decades of American administration. There were two main reasons for this. First, the cost of obtaining secure property rights was too high, mainly because of technical constraints, and the government did not fully subsidize the process. Second, the cost of not having secure property rights was not very high for individual Filipino families: the Philippines did not experience high rates of property crime, and the government was reluctant to enforce property rights too strictly for political reasons.

\section{The Redistribution of Friar Lands}

On the surface, the government disposed of the friar lands relatively rapidly. By 1910, it had sold 34 percent of the available land area. ${ }^{35}$ By 1913, that number had increased to 61 percent. ${ }^{36}$ The government, however, had to take special measures in order to achieve this goal. The average sale price for a hectare of friar land was US\$131, considerably higher than the average value of US\$114 per hectare in the rest of Luzon. ${ }^{37}$ This difference was due to the high purchase price paid to the friars, which the government wanted to recoup; the evidence suggests that friar lands were not more productive than other lands. ${ }^{38}$ In order to help purchasers, the government loaned the purchase price to the tenants at 6 percent interest. The government also created an additional fund that would make loans at a fixed rate of 12 percent for seedling, machines, livestock, and the construction of warehouses, rice mills, and other improvements. ${ }^{39}$

\footnotetext{
35 Calculated from figures in Escalante, Friar Lands, pp. 130 and 134.

361913 Report of the Philippine Commission, p. 148.

371915 Report of the Philippine Commission, pp. 81-83. We have converted all prices from pesos to dollars at the fixed exchange rate of 2:1.

38 Rice yields in provinces with friar lands in 1903 were 12 hectoliters per hectare, compared with 16 in other provinces. The corresponding figures for 1918 were 22.5 and 28 hectoliters per hectare (authors' calculations from the 1903 census).

39 Escalante, Friar Lands, p. 132.
} 
Despite these measures to help the peasants to purchase friar lands, they were still too expensive. Many of the new owners rapidly became delinquent on their loans. Delinquencies hovered around 25 percent of contracted income. (See Table 2.) However, the government, fearing unrest, tended to be very lenient towards delinquent farmers, be they owners or tenants. Very few were ever evicted from their lands. For instance, a severe drought in 1912 caused delinquencies to spike the next year, yet evictions did not increase substantially until 1915.

\section{TABLE 2 AROUND HERE}

The Philippine Commission estimated that one hectare of good rice land could generate (at 1915 prices) approximately US\$60 worth of rice every year. After taking into account expenditures on inputs, the Commission estimated that this would result in an effective annual income of US\$52 per hectare. Given an eight-year amortization schedule and 6 percent interest, the Commission estimated that loan repayments would amount to 22 percent of the typical family's annual income, a not inconsiderable burden in a country where few families enjoyed incomes much beyond the subsistence level. $^{40}$ Renting the same land was considerably cheaper: the annual rent worked out to only $11.5 \%$ of annual income.

\section{Land Titling}

The progress of land titling was relatively slow and concentrated towards large farms. As Table 3 shows, about 88,257 farms (accounting for about 900,000 hectares) had been issued Torrens titles by 1918. This represented $4.5 \%$ of all farms and $19.6 \%$ of all farm area, suggesting that it was predomi-

\footnotetext{
401915 Report of the Philippine Commission, pp. 81-83.

41 Philippine Government, The Friar-Land Inquiry, p. 175. Both sets of figures based on calculations for first class irrigated land on the Imus estate. Note that alternative accounts present an even worse picture: for instance, Felipe Topacio of the Imus estate claimed that his land produced only $\$ 52.50$ worth of rice in a year, while his obligation to the government, including interest charges, was $\$ 61.60$. See Escalante, Friar Lands, p. 136.
} 
nantly large farmers who managed to obtain Torrens titles. ${ }^{42}$ Overall, the majority of farms (58.4\%) had no title of any kind. The remainder either possessed Spanish royal titles (3.1\%), possessory titles (7.0\%), judicial decrees (1.5\%) or private deeds (22\%).

\section{TABLE 3 AROUND HERE}

The main problem appears to have been the high cost of implementing the Torrens system. We demonstrate that the costs were high relative to farmers' incomes and government revenues. The government's fiscal situation did not leave room to further subsidize titling programs. Finally, we consider why other potential means of lowering costs were not adopted.

The cost of a Torrens titling program included the overhead cost of setting up the land court and land registry, and the cost of sending professional surveyors out to create new titles — surveyors were not common in the Philippines (most were, in fact, either American or Japanese) and their services were very expensive. In addition, a good-faith search needed to undertaken to insure that there were no conflicting liens or titles: this involved sending a government official to interview the neighbors and canvass local notaries. Finally, the assurance fund needed to be fully funded. The Philippine territorial government charged a flat rate of $\$ 10$ per parcel to cover surveying and titling costs. In addition, the government charged a premium of 1.0 percent of the property's assessed value for the assurance fund and an additional fee worth $0.1 \%$ to pay for the examination of title. The total cost of a Torrens title, then, came to 9.9 percent of the value of the average hectare of Philippine rice land. Given the high fixed cost of acquiring a title, it is not surprising that only larger farms were likely to apply for title.

In fact, \$10 per parcel was probably not sufficient to cover the cost of titling. A similar procedure of surveying and verifying claims was required to register a homestead on public lands, and in 1911,

\footnotetext{
42 We should note that the 1918 census figures are somewhat different than these figures, which were compiled by Philippine statisticians in 1937. The 1918 census reported 70,685 farms as having been issued Torrens titles, or only 3.6\% of the total number of farms.

43 In theory, private deeds had to trace a chain of ownership back to a Spanish royal title, even if that title was not in the hands of the landowner.
} 
the Secretary of the Interior for the insular government, Dean Worcester, reported to Congress that the fixed cost of inspecting, surveying, and registering a homestead was $\$ 25$ per parcel. $^{44}$

What would it have cost to subsidize a comprehensive land titling program? Using data from the 1918 census, we estimated the cost of a universal Torrens titling program. (See Table 4.) We compute two sets of cost estimates. The low estimate uses a fixed cost of $\$ 10$ per parcel, and assumes that only farms possessing no titles at all were to be given Torrens titles. This comes to around $\$ 11.86$ million, which amounted to 37 percent of annual insular government revenue. Given that much of the insular government's revenue was already used to subsidize municipal and provincial governments, pay interest on existing debt, or cover the operating costs of government-owned enterprises like the post office, public ferries, and railroads, the government would have realistically needed to spend around 57 percent of its annual discretionary income to subsidize land titling.

\section{TABLE 4 AROUND HERE}

We also computed a high estimate of the cost of titling by assuming that all farms which did not have Torrens titles would need to get one. The cost estimate then works out to $\$ 19.6$ million or $94 \%$ of government revenue after subsidies to provinces and the operating costs of commercial and industrial units.

Could the Philippine government have raised taxes to finance an expansive land-titling program? The answer is: probably not. The Philippines was not a low-tax nation compared to other East Asian colonies, the independent states of Latin America, or even the contemporary United States. (See Table 5).

TABLE 5 AROUND HERE

\footnotetext{
44 61st Congress, Administration of Philippine Lands, pp. 1177-78. Worcester also estimated that it cost $\$ 40$ per parcel to sell public lands, which the law allowed the government to do in small plots of 16 hectares for an individual and 1024 hectares for a corporation, provided that the corporation's shareholders did not own other landowning corporations.
} 
Would it have been politically feasible for the U.S. metropolitan government to subsidize Philippine land reform? Once again, the answer is probably not. The U.S. War Department already spent an average of \$10 million a year on the Philippines, amounting to roughly 4\% of Philippine GDP (see Table 6.) Much of this spending was not directly related to external defense: between 1902 and 1914, roughly $16 \%$ of all defense spending went to purchase supplies in the Philippines or pay the Philippine scouts; another 11\% went to public services (like the census or the geodetic survey), construction, or emergency food aid. If Washington were to subsidize the land titling program, even the lowest estimate of \$11.86 million was higher than average War Department spending in the Philippines. It would therefore have been difficult to convince Congress to approve this additional spending, especially given that a quarter of War Department expenditure already went to “developmental” purposes.

\section{TABLE 6 AROUND HERE}

Absent new tax revenues, of course, the insular government also could have borrowed to finance property rights reform. Our cross-sectional evidence (discussed later on) implies that such reforms would have little effect on economic growth in the medium run: provinces with lots of titling (or more formal agricultural credit) enjoyed no faster agricultural growth than provinces without titling. The government, then, would have to finance interest payments out of other revenues, placing an equivalent strain on the budget.

\section{Securing Tenure on Public Lands}

What about the homestead act? Progress was slow in issuing titles to existing squatters. In fact, the Commission did not begin to clear the backlog of applications until 1910, by which point more than 15,000 families had placed claims that they had occupied public land before 1898. By 1918, about 11,000 applications had been processed by the Director of Public Lands, and an equal number were still pending. 
The government was more efficient in processing homesteads. Between 1904 and 1914, the homestead bureaucracy cleared an average of 48 percent of all new applications. This rate was not enough to prevent the accumulation of a substantial backlog of applications, but it was much better than the rate for free-patenting. It should be noted that more homestead applications were rejected than approved.

As in the case of friar land redistribution, a major reason for the slow speed of processing homestead and free-patent applications was the difficulty of conducting surveys. Rather than survey first and then distribute, the U.S. decided as an economy measure to survey only as applications came in. This drove up the cost of the program in both time and money. The costs of such surveys were compounded by the fact that many of the applicants for free-patents were not currently occupying the land, having been displaced by the violence of the Philippine Revolution (against the Spanish) of 1896-98 or the Philippine War (against the Americans) of 1899-1902. By 1918, 60 percent of all the farms that the census recorded on public lands still lacked a title, and only 2.2 percent of public land had been settled through homesteads or free-patenting. ${ }^{45}$ As in the land titling process, homestead applicants were charged a fixed fee of $\$ 10$ per parcel, which they could pay in four installments. Given that the risk of eviction was not very high (see next section) for squatters on public lands, there was little reason for a Philippine pioneer to pay the cost of applying for formal ownership.

Could the Philippines have adopted other measures to reduce the cost of surveying? For instance, Mexico invited private survey companies to survey their extensive public lands in return for one-third of the land as compensation. This move resulted in about $28 \%$ of the entire country being surveyed in just a decade. However, only two-fifths of the survey companies fulfilled their contracts, and received land in compensation, and many surveys were of poor quality. There was also little evidence that

\footnotetext{
45 Area calculated from figures in Miller, Economic Conditions, p. 263.
} 
these surveys were profitable for the companies. ${ }^{46}$ It is therefore not clear that private companies would have come forward to undertake such large-scale surveying; such a program would also have been in conflict with the U.S. goal of limiting American companies' investments in the Philippines.

An alternative option would be to conduct large-scale cadastral surveys for an entire area at a given time, rather than piecemeal surveys for individual plots at the time of application. A cadastral law was passed in 1912, calling for nationwide surveys. An initial test in Pangasinan province resulted in more than 900 parcels being surveyed in three weeks, at a cost of $\$ 3.75$ per parcel. ${ }^{47}$ However, these economies did not hold up on a larger scale: estimates from 1915 indicate that 8724 parcels were surveyed that year at a cost of $\$ 107,788$ i.e. at a rate of $\$ 12$ per parcel. ${ }^{48}$ The director of lands estimated that it would cost about \$25 million to complete the cadastral survey of the islands, a figure higher than our estimates in Table $4 ;^{49}$ in fact, a working cadastral register was not completed during the American occupation era.

A final option would have been to use self-certification as a basis for certifying ownership, assuming that an absence of objections from neighboring farmers indicated the acceptance of such claimed property rights. In fact, the census definition of ownership was changed to "all persons who, with or without legal title to, or possession of, real property, have... subscribed under oath a declaration that such property belonged to them.” However, Corpuz claims that this resulted in several small farmers losing their fields and becoming tenant-sharecroppers. ${ }^{50}$

\footnotetext{
46 Holden, Mexico and the Survey of Public Lands, p 57.

47 Forbes, “The Philippine Islands,” p. 147.

48 Report of the Philippine Commission 1915, p 84

49 Report of the Philippine Commission 1913-14, p 41.

50 Corpuz, An Economic History, p 282.
} 


\section{LAND OWNERSHIP AND DISTRIBUTION, 1903-1918}

We used data from the comprehensive censuses carried out by the U.S. administrators in the Philippines in 1903 and 1918 to document the trends in land use, tenure security and the distribution of farm sizes. We document three main trends related to land in this period: a major expansion of the cultivating frontier, a rise in the incidence of squatting and a persistently unequal distribution of farm sizes. There was also a significant increase in rice yields over this period. (See Appendix 1.) ${ }^{51}$

\section{The Expansion of the Frontier}

As mentioned earlier, the Philippines was a frontier economy in 1903-18 (see Table 1.) Land was relatively underutilized: only $17 \%$ of the total land area had been claimed as farm land in 1903, and only $47 \%$ of the farm land was under cultivation. In addition to abandoning the Spanish policy of holding public lands as an asset to be sold, the U.S. further encouraged frontier expansion by building railroads, turnpikes, and public ferry services.

Between 1903 and 1918, land utilization increased on both the extensive and the intensive margins. By 1918, farms claimed $26 \%$ of the total land area, and $56 \%$ of all farmland was under cultivation. The net effect was a $67 \%$ increase in total cultivated area. Over this same period, the population of the Philippines expanded by only 32\%, which meant that the country's population density on cultivated land declined. This expansion of the frontier meant that conflicts over land were few, despite the slow progress of land rights formalization.

What relationship should we expect between the expansion of the frontier and the trends in property rights? Providing secure property rights to farmers might encourage them to cultivate new lands in the hope of greater returns. On the other hand, with the farming population on the move towards new areas, it might become logistically difficult to verify land claims and issue land titles or approve

51 We dropped Manila City from all our regressions, mainly because it had less than 1000 hectares of farm area in 1918. 
homestead claims. In empirical analysis using province level data, we do not find any differences in the expansion of cultivated area across friar and non-friar provinces, or across provinces with a greater or lesser extent of Torrens titles or other types of titles. Provinces that were more populous, and those that were already relatively intensively farmed saw faster expansion than other provinces, implying that frontier expansion was relatively steady, rather than leapfrogging across the archipelago. (See Table 7.) ${ }^{52}$

\section{TABLE 7 AROUND HERE}

\section{The Rise in Informal Tenure}

What about the distribution of ownership types? The census data revealed a startling fact: there was a deterioration in the share of the population possessing formal property rights between 1903 and 1918. The share of cultivated area held by people who have a "no rental" status (i.e. neither ownership nor tenancy) increased from 2.4 percent to 7.5 percent over the period 1903-1918 (Table 8). Following officials in the Bureau of Insular Affairs and Department of the Interior, we use the term "squatters" to refer to this category of landholders. We should note that squatting and lacking a formal title are not the same thing: 58 percent of farms lacked a formal title, but only 7.5 percent were occupied by families with no ownership rights or tenancy contracts whatsoever.

\section{TABLE 8 AROUND HERE}

What might explain the increase in the incidence of squatting? We consider four hypotheses. The first is that in areas of rapid frontier expansion, the occupants of previously uncultivated land may not have had time to register their claims. This hypothesis predicts a positive relationship between the expansion of cultivation and the increase in squatting.

\footnotetext{
52 Frontier expansion does not seem to be a "safety valve" to reduce political violence. We included the number of people convicted in 1902 as an additional regressor in our regressions, and this turns out to be completely insignificant. In fact, the census of 1903 comments, “...the proportion number of criminals in confinement was less than 8 in each 10,000 of population. In the United States in 1890, there were about 13 in each 10,000 of the inhabitants...this showing is not only favorable but remarkable, and indicates that the Filipinos as a race are not especially disposed toward crime." (Census of 1903, Volume IV, p. 417). See Garcia-Jimeno and Robinson, "The Myth of the Frontier" for a cross-country analysis relationship between the existence of a frontier, political institutions and economic development.
} 
The second hypothesis is that the cost of obtaining a formal title dissuaded claimants. If this hypothesis is correct, we would expect to see more squatting in poorer provinces (because the average resident would be less able to afford the associated fees) and in provinces with higher property tax rates (because the incentive to avoid formal registration — and thus taxes — would be greater).

The third is that a low risk of dispossession dissuaded people from registering their land claims. An increase in population density on cultivated land indicates greater competition for the land. Areas with more titled farms reflect the presence of landowners with legal means to evict squatters. We take the number of land crimes as a proxy for the risk of dispossession by private parties. If this hypothesis is correct, then there should be a negative relationship between squatting and our independent variables. Our final hypothesis is that the government was reluctant to evict squatters. ${ }^{53}$ If this hypothesis is correct, then the amount of public land in a province should be positively related to the amount of squatting.

We tested these hypotheses using province-level data from the censuses of 1903 and 1918 on the variables identified above. We computed two measures of the extent of informal tenure: the fraction of farms occupied by squatters and the fraction of cultivated area occupied by squatters in each province. The signs on most of our coefficients were in line with our hypotheses listed above: more public land, higher levels of property tax, a wider distribution of any kind of land titles, lower agricultural wages and decreases in population density increased the extent of squatting.

\section{TABLE 9 AROUND HERE}

The only coefficient which is statistically significant on a consistent basis is the extent of public lands. In other words, the main determinant of squatting appears to have been the availability of open government-owned land under American jurisdiction. A 10 percentage point increase in the

53 61st Congress, Administration of Philippine Lands. 
fraction of public land in the province was associated with a 0.56 - 0.66 standard deviation increase in the incidence of squatting.

Were there other costs to informal land ownership? Squatters might have had to forego access to formal credit or access to irrigation. We ran regressions using both the value of formal credit (normalized for land area) and access to irrigation as our dependent variables. In no specification was the coefficient on squatting significant, and its sign changed from negative to positive with the addition of a dummy variable for access to railroads. In short, informality appeared to have little effect on the overall level of farm credit or access to irrigation. ${ }^{54}$

Why weren't property rights more determinative of access to irrigation or credit? In the case of irrigation, the answer is that the insular government subsidized access regardless of formality. In 1908 the insular government created the "Special Permanent Fund" for irrigation, under which any province, municipality, or "group of neighborhoods" could apply for funding for irrigation projects as long as they would agree to charge sufficiently high fees for the water to reimburse the insular government for construction within 20 years at no interest. ${ }^{55}$ In 1912, disappointed with the slow pace of irrigation projects, the insular government altered the law to give the Secretary of Commerce and Police the authority to initiate projects unless more than half the landowners a given area registered an objection. (The law did not specify whether the landowners needed to produce formal titles.) The pace of irrigation projects picked up considerably. ${ }^{56}$

Agricultural credit was mostly provided outside the formal credit system through local moneylenders. Such loans were made at very high rates of interest, generally collateralized by livestock or other forms of mobile capital and not by land. In 1908, the insular government established the Agricultural Banks of the Philippines, capitalized at $\$ 500,000$. Unfortunately, the Agricultural Bank -

\footnotetext{
54 Results available upon request.

551908 Report of the Philippine Commission, vol. II, page 470.

56 Elliot, The Philippines to the End of the Commission, pp. 366-69.
} 
which lent only to landowners who could produce formal titles — proved unable to attract many deposits, and exhausted its resources by 1913. In 1915 the government changed track and passed legislation providing for the formation of credit cooperatives. ${ }^{57}$ Cooperative loans did not require formal title; just an application describing the borrower's land, the uses to which the loan would be put, and the signatures of two "responsible guarantors.” By 1918, the 243 credit cooperatives provided almost all the formal agricultural credit in the Philippines.

In short, the evidence suggests that, owing to budgetary constraints, the U.S. failed to set up a secure property rights system. In addition, the small size of the formal banking system and widespread subsidization of rural credit cooperatives and irrigation meant that some of the benefits of formal property rights were attenuated. The lack of de jure property rights was thus compensated by de facto security of informal squatting on public lands, as well as these initiatives to mitigate the downsides of not having formal property rights. The presence of a rapidly expanding frontier, by reducing the likelihood of conflicts over land, was also conducive to the continuation of informality.

\section{Trends in Land Inequality}

Much of the literature on land inequality argues that the farm size is an important determinant of agricultural investments and productivity. ${ }^{59}$ In addition, the Americans wanted to insure an equitable distribution of land regardless of its impact on farm productivity.

The census data reveals that both the number of smaller farms and the share of land occupied by such farms rose during the first 15 years of American rule. In 1903, 440,000 farms smaller than one hectare occupied 7.2\% of farm area and 10.5\% of cultivated land. By 1918, the total number of such small farms had almost tripled to 1.2 million, and they occupied $11.4 \%$ of farm area and $14.6 \%$ of

\footnotetext{
57 Elliot, The Philippines to the End of the Commission, p. 373.

58 Russell, Outlook, p. 199.

59 See Binswanger et al, "Power," for an overview of the theoretical and empirical literature on the determinants of farm size, as well as the impact of farm size on productivity.
} 
lands under cultivation. Over this same period, there was a drop in the number and share of area held farms of more than 15 hectares. In 1903, nearly 49\% of farm area and 34\% of cultivated area was inside large farms. In 1918 those numbers had fallen to $40 \%$ and $27 \%$.

These changes, however, were not very large in terms of changing the overall land distribution. ${ }^{60}$ (See Figure 1a.) The nationwide Gini coefficient of 0.75 remained almost the same across these two years. Land inequality fell a bit at the top of the land distribution and increased in the bottom: in other words, the "landed elite” appears to have been broadened at the expense of smallholding families. In addition, rough national stagnation masks provincial variation in the change in land inequality. The redistribution of the friar estates did have an impact: we do see greater equality at the top end of the farm size distribution in friar provinces (see Figure 1b) - e.g., an expansion of the "landed elite” in those areas — but this was offset by increasing inequality among the smallholders.

\section{FIGURES 1a AND 1b AROUND HERE}

We do not find the province level increases in inequality to be driven by any specific policy variables (see Table 10). For instance, we might expect to see lower inequality in the friar land provinces. We also might expect to see lower inequality in frontier provinces, since the Americans designed their frontier policy to favor small homesteaders (or, de facto, small-scale squatters). Since the American government appears to have been effective at protecting formal property rights where they existed, we might also expect provinces where more farms enjoyed formal titles to see a greater expansion by small farmers, since they might expect their property rights to be protected in the future as well. Finally, if squatting increased in the province, we expect it to be mainly due to small farmers.

\section{TABLE 10 AROUND HERE}

The data do not support any of these hypotheses. We computed Gini coefficients for each province, as well the fraction of cultivated land in farms of less than 2 hectares and the fraction of cultivated land

\footnotetext{
60 The Lorenz curve graphs the cumulative fraction of farm area in different size categories against the cumulative fraction of total farms in that size category. A 45 degree line would represent a perfectly equal distribution of land i.e. small farms which constitute $31 \%$ of all farms would also control $31 \%$ of cultivated area and so on.
} 
in farms greater than 15 hectares. The signs on most of the coefficients were wrong, and none of the results were statistically significant. The implication is that the Americans' hands-off policy with regard to the frontier failed to systematically discriminate in favor of smaller farmers. Rather, the existing Philippine land distribution replicated itself in the new frontier.

\section{Trends in Agricultural Productivity}

Despite the lackluster progress of land reforms, agricultural productivity increased significantly

between 1902 and 1918. ${ }^{61}$ The per-hectare yield of rice increased from 210 kilos per hectare in 1902 to 384 kilos in 1918. Other crops, such as corn, hemp and sugarcane exhibited similarly large increases. However, most of these gains appear to have taken place in the years after 1915. Agriculture in the Philippines was subject to many natural shocks: a rinderpest epidemic which killed half of all carabao bulls (the main draft animal) in 1902, in addition to locust plagues, and a devastating drought in 1912. In fact, rice yields in 1915 were still lower than in 1896. (See Figure 2.)

\section{FIGURE 2 AROUND HERE}

What explains the increase in the yields over the period? We regressed the change in provincelevel yields from the 1903 and 1918 censuses on a number of factors: change in acreage (overall acreage and acreage devoted to rice), change in capital and labor inputs (carabao bulls per hectare, irrigation, credit availability, population density) and change in other facilitating infrastructure (construction of railroads and rice mills). None of these variables predict the change in yields in a statistically significant way (results available upon request). Nor does the increase in squatting appear to have a significantly negative impact on the yield increases (though the coefficient is negative, suggesting that there might have been a small cost). The growth in agricultural productivity after 1915 thus appears to have been secular trend that affected the entire archipelago fairly uniformly. Later

61 The 1903 census enumeration actually took place during 1902. 
studies suggest that this increase in yields was a permanent one; however, there was no further increase in rice yields after 1920 until the Green Revolution in the 1960s.

What then explains the one-time jump in yields? The main factor appears to have been a government initiative. Agricultural research in the Philippines began in 1909, with the identification of over 1000 varieties of seeds. After several years testing which strains grew best on the islands, in 1914 the “food production campaign” began to distribute seeds to farmers through the Bureau of Agriculture in continuously increasing quantities. In 1917, over 77,000 kg of seeds were distributed to farmers. ${ }^{63}$ The timing of this program thus coincides neatly with the observed increase in yields. Increased demand for food grains during the First World War might also have played a role in increasing output, but there is no reason to suppose that such an increase would have been sustained.

\section{LAND REFORMS IN KOREA AND TAIWAN}

Immediately after the Second World War, the U.S. facilitated land reforms in Korea (1945-50) and Taiwan (1949-53). These reforms resembled many of the reforms that the U.S. had attempted in the Philippines a half-century earlier. The reforms purchased large estates and redistributed them to their tenants (similar to the redistribution of the friar lands) and confiscated and redistributed formerly Japanese-owned lands in both countries (similar to the homestead program). The Korean and Taiwanese reforms succeeded in increasing land ownership and reducing tenancy, with no increase in squatting. In Korea, the proportion of farm households who owned their farms increased from 17 percent in 1947 to 70 percent in 1965 . $^{64}$ In Taiwan, the proportion of private farmland farmed by tenants fell from 39 percent to 15 percent.

\footnotetext{
62 Bautista and Javier, “Evolution,” p.3.

63 Borja, Torres, and Octubre, "Fifty Years,” and Constantino and Honrado, "Seeds and Plants.”

64 Lee, “Peasant Farming,” p. 494.

65 Yager, Transforming Agriculture, p. 118.
} 
Why did the Korean and Taiwanese reforms succeed when the earlier U.S. attempt at land reform in the Philippines failed? In part, the U.S. appears to have learned some lessons from its Philippine experience in carrying out later reforms in Korea and Taiwan. In the absence of any legal limits akin to those imposed by the Treaty of Paris, the Korean and Taiwanese reforms deliberately tried to minimize the cost of land acquisition. The reforms capped sharecropper rents at 37.5 percent of output before purchasing any lands. As a consequence of the rent caps, many landlords sold their land in the open market at depressed prices. ${ }^{66}$ The reforms then limited compensation when acquiring land for redistribution, in sharp contrast to the purchase of the friar lands. The Korean reform capped compensation at 1.25 times the value of annual yield, when land values in 1940 averaged five times the annual yield. $^{67}$ Similarly, Taiwan capped compensation at 2.5 times the annual yield, when the historical market value of Taiwanese paddy land in 1914-43 ranged between four to six times the annual yield. $^{68}$

In addition, U.S. taxpayers directly subsidized the administrative costs of the Korean and Taiwanese reforms, through the American Military Government and National Land Administration in Korea and the Joint Commission on Rural Reconstruction in Taiwan. In both cases, this funding was in addition to American spending on defense and relief. The key difference was that in the context of the Cold War, Congress was willing to appropriate yet more taxpayer money to subsidize land reforms in its allied territories.

The reforms in Korea and Taiwan, however, differed from the earlier Philippine reforms in one key respect: their administrative costs were considerably lower than in the Philippines, because detailed land records and a system of formal property rights already existed. The Japanese conducted

\footnotetext{
66 In Korea, almost half of all land targeted for land reform was sold by landlords before land redistributions began in 1950. Jeon and Kim, “Land Reform,” p. 255.

${ }^{67}$ This policy effectively expropriated three-quarters to seven-eighths of the land value from the landlords. Lee, “Peasant Farming,” p. 508.

68 Taiwan's reform thereby transferred an estimated 13\% of GDP from landlords to their former tenants. Yager, Transforming Agriculture, p. 120 .
} 
prolonged and expensive cadastral surveys in Taiwan in 1898-1903 and Korea in 1911-18 (financed by the central government) which mapped and titled 19 million lots in Korea alone. ${ }^{69}$ In addition, both nations were relatively crowded and lacked a frontier: squatting was not an attractive alternative for peasants in either place, raising the incentive for peasants to acquire secure property rights. In other words, the United States helped redistribute property rights in Korea and Taiwan after the Second World War, but unlike the Philippines a half-century earlier, it did not have to create them.

\section{CONCLUSION}

There is a general consensus among economists that a system of transparent and secure property rights is beneficial for growth and development. A large literature emphasizes the role of property rights in spurring long-term investments, improving productivity, changing labor allocations and increasing access to formal sources of credit. ${ }^{70}$ The U.S. administration in the Philippines realized these benefits, and attempted to create just such a system of property rights during the two decades preceding the Philippine Autonomy Act.

In this paper, we documented the fact that three major property rights reforms - the redistribution of friar lands, the issuance of formal land titles and the granting of homestead rights-were all implemented very slowly by the U.S. administration in the Philippines. The major obstacle appeared to be the high cost of establishing a system of clear and enforced property rights. ${ }^{71}$ We documented evidence of budget constraints which prevented the Philippine government from devoting more resources to the process. Political constraints made it difficult for Washington to provide further funding. Finally, the low levels of property crime, the presence of a rapidly expanding frontier, and the reluctance of the government to evict squatters from public land served to lower the willingness of

\footnotetext{
69 Myers and Saburo, “Agricultural Development,” pp. 428-29, and McCune, “Land Redistribution,” p. 14.

70 See, among others, De Soto Mystery of Capital, Do and Iyer “Land Titling,” Field "Entitled to Work,” Knack and Keefer “Institutions,” North and Thomas, Western World, Banerjee, Gertler and Ghatak “Empowerment,” and Galiani and Schargrodsky "Property Rights.”

71 Torres et al "Colombia” makes a point similar to ours regarding the high transaction cost of land titling.
} 
farmers to pay for formal property rights. Comparing the Philippine experience with the land reforms in Korea and Taiwan strengthens this conclusion; the latter two countries devoted considerably more resources to the land reform process, both by expropriating landlords and from U.S. funding for administrative costs.

Despite the lack of formal property rights, agricultural productivity and diversification increased in the Philippines during this period. This is likely due to the fact that property rights were fairly secure de facto, and because of policies which did not restrict access to irrigation or credit facilities on the basis of formal land ownership. Other U.S. investments, such as the development and distribution of improved seeds, probably served a major cause of the observed one-time increase in yields. 


\section{REFERENCES}

1898 Annual Reports of the Navy Department (Washington: GPO, 1898).

1901 Report of the Philippine Commission, Volume 4 (Washington: GPO, 1901).

1903 Report of the Philippine Commission (Washington: GPO, 1903).

1903 Census of the Philippine Islands, (U.S. Bureau of Census, Washington, 1905).

1906 Report of the Philippine Commission to the Secretary of War (Washington: GPO, 1907).

1908 Report of the Philippine Commission to the Secretary of War, Volume 2 (Washington: GPO, 1909).

1908 Yearbook of Agriculture, USDA, (Washington: GPO, 1909).

1912 Report of the Philippine Commission (Washington: GPO, 1913).

1912 Yearbook of the U.S. Department of Agriculture (Washington: GPO, 1913).

1913 Report of the Philippine Commission to the Secretary of War (Washington: GPO, 1914).

1915 Report of the Philippine Commission to the Secretary of War (Washington: GPO, 1916).

1916 Report of the Philippine Commission to the Secretary of War (Washington: GPO, 1917).

1918 Census of the Philippine Islands, (Manila: U.S. Bureau of the Census, 1920).

1918 Report of the Auditor for the Philippine Islands (Manila: Bureau of Printing, 1919).

1919 War Department Annual Report, Vol. 3 (Washington: GPO, 1920).

1919 Yearbook of the U.S. Department of Agriculture (Washington: GPO, 1920).

1921 Yearbook of Agriculture, USDA (Washington: GPO, 1922).

Philippine Government. 1910. The Friar-Land Inquiry (Manila: Bureau of Printing).

Presidential Messages and State Papers, Vol. VIII (New York: The Review of Reviews Company, 1917).

Report of the (Schurman) Philippine Commission to the President. 1900. (Washington: GPO).

Reports of the (Taft) Philippine Commission, the Civil Governor and the heads of the executive de-

partments of the civil government of the Philippine Islands (1900-1903). 1904. (Washington: Bureau of Insular Affairs).

The Oxford Latin American Studies Database, http://oxlad.qeh.ox.ac.uk.

Philippine Insurgent Records, 1896-1901, National Archives, Washington, D.C.

The Philippine Statistical Review 4 (1-2), First and Second Quarters, 1937.

61st Congress, $3^{\text {rd }}$ Session, H.R. Report \#2289. 1911. Administration of Philippine Lands (Washington: GPO).

Philippine Government, Bureau of Lands. 1906. Primer containing Questions and Answers on the Public Land Laws in force in the Philippine Islands (Manila: Bureau of Printing).

Álfaro, Laura, Noel Maurer, and Faisal Ahmed. 2008. “Gunboats and Vultures: Market Reaction to the Enforcement of Sovereign Debt.” Harvard Business School, mimeo.

Alston, Lee, Gary Libecap, and Bernardo Mueller. 1998. "Property Rights and Land Conflict: A Comparison of Settlement of the U.S. Western and Brazilian Amazon Frontiers," in Latin America and the World Economy Since 1800, edited by John Coatsworth and Alan Taylor (Cambridge: Harvard University Press): 55-84. 
Banerjee, Abhijit, Paul Gertler, and Maitreesh Ghatak. 2002. "Empowerment and efficiency: Tenancy reform in West Bengal.” Journal of Political Economy 110(2): 239-280.

Bassino, Jean-Pascal, and Pierre Van der Eng. 2005. "New Benchmark Estimate of Levels of Wages and GDP, 1913-1970.” Australian National University, mimeo.

Bautista, Eulito, and Evelyn Javier. 2005. “The Evolution of Rice Production Practices.” Philippine Institute for Development Studies Discussion Paper No. 2005-14.

Berkowitz, Daniel, and Karen Clay. 2004. "Initial conditions, institutional dynamics and economic performance: Evidence from the American states.” Mimeo.

Berkowitz, Daniel, Katharina Pistor, and Jean-Francois Richard. 2003. "Economic Development, Legality, and the Transplant Effect.” European Economic Review 47: 165-195.

Besley, Timothy and Robin Burgess. 2000. "Land Reform, Poverty Reduction and Growth: Evidence from India.” Quarterly Journal of Economics 115 (2): 341-388.

Binswanger, Hans, Klaus Deininger and Gershon Feder. 1995. "Power, distortions, revolt, and reform in agricultural land relations," in Handbook of Development Economics. Volume 3, edited by J. Behrman and T.N. Srinivasan (Amsterdam: North-Holland): 2659-2772.

Booth, Anne. 2007. "Night Watchman, Extractive, or Developmental States? Some Evidence from Late Colonial South-East Asia.” Economic History Review, 60(2): 241-266.

Borja, Victoriano, J.P. Torres and Francisco Octubre. 1952. "Fifty Years of Rice Research,” in A Half-Century of Philippine Agriculture (Manila: Bureau of Agriculture, Graphic House): 179189.

Clay, Karen. 1999. "Property Rights and Institutions: Congress and the California Land Act of 1851,” The Journal of Economic History 59(1): 122-142.

Clay, Karen. 2006. "Uncertain Property Rights and Agricultural Production: Evidence from PostGold-Rush California,” Carnegie Mellon University, mimeo.

Constantino, Marecelino, and Primo Honrado, "Seeds and Plants,” in A Half-Century of Philippine Agriculture (Manila: Bureau of Agriculture, Graphic House): 220-230.

Corpuz, Onofre. 1997. An Economic History of the Philippines (Manila: University of the Philippines Press.)

De la Cavada, Agustín. 1876. Historia Geografica, Geologica y Estadistica de Filipinas (Manila).

De Soto, Hernando. 2000. The Mystery of Capital: Why Capitalism Triumphs in the West and Fails Everywhere Else (New York: Basic Books).

Do, Quy-Toan and Lakshmi Iyer. 2008. "Land Titling and Rural Transition in Vietnam.” Economic Development and Cultural Change 56(3), 531-579.

Elliott, Charles. 1917. The Philippines to the End of the Commission Government (Indianapolis: Bobbs-Merrill).

Escalante, Rene. 2002. The American Friar Lands Policy (Manila: De La Salle University Press).

Field, Erica. 2007. “Entitled to Work: Urban Tenure Security and Labor Supply in Peru.” Quarterly Journal of Economics 4(122): 1561-1602.

Forbes, W. Cameron. 1945. The Philippine Islands (Cambridge, MA: Harvard University Press). 
Galiani, Sebastian, and Ernesto Schargrodsky. 2006. "Property rights for the poor: Effects of land titling." Mimeo.

Garcia-Jimeno, Camilo and James Robinson. 2009. “The Myth of the Frontier.” NBER Working Paper No. 14774.

Gates, John. 1977. "Philippine Guerrillas, American Anti-Imperialists, and the Election of 1900,” Pacific Historical Review 46(1): 51-64.

Haber, Stephen, Noel Maurer, and Armando Razo. 2003. "When the Law Does Not Matter: The Rise and Decline of the Mexican Oil Industry.” Journal of Economic History 63(1): 1-31.

Holden, Robert H. 1994. Mexico and the Survey of Public Lands: The Management of Modernization 1876-1911 (DeKalb, IL: Northern Illinois University Press).

Hoover, Herbert. 1952. The Memoirs of Herbert Hoover: The Cabinet and the Presidency, 1920-33 (New York: MacMillan).

Iyengar, Radha, and Jonathan Monten. 2008. “Is There an 'Emboldenment' Effect? Evidence from the Insurgency in Iraq.” NBER Working Paper No. W13839.

Jeon, Yoong-Deok, and Young-Yong Kim. 2000. "Land Reform, Income Redistribution and Agricultural Production in Korea.” Economic Development and Cultural Change48(2) : 253-268.

Knack, Steven, and Philip Keefer. 1995. "Institutions and economic performance: Cross-country tests using alternative measures.” Economics and Politics 7: 207-227.

Kramer, Paul. 2006. Blood of Government: Race, Empire, the United States, \& the Philippines. (Chapel Hill: University of North Carolina Press).

Kumar, Dharma. 1982. “The Fiscal System,” in Dharma Kumar and Tapan Raychaudhuri, eds., The Cambridge Economic History of India Volume 2 (Cambridge University Press).

La Croix, Sumner. 2006. “Outlying Areas,” in Historical Statistics of the United States, Millennial Edition, Volume 5 (New York: Cambridge University Press): 587-625.

La Croix, Sumner, and James Roumasset. 1990. "The Evolution of Private Property in NineteenthCentury Hawaii,” The Journal of Economic History, Vol. 50, No. 4 (Dec.,), pp. 829-852.

Latham, A.J.H. 2008. "Climatic Fluctuations and the International Rice Trade: A Preliminary Investigation,” Swansea University, mimeo.

Lee, Eddy. 1979. "Egalitarian Peasant Farming and Rural Development: the Case of South Korea," World Development 7: 493-517.

Legarda, Benito. 1999. After the Galleons (Manila: Ateneo de Manila Press).

LeRoy, James. 1905. Philippine Life in Town and Country (New York: G. P. Putnam's Sons).

Malcolm, George. 1916. The Government of the Philippine Islands. (Rochester, NY: The Lawyers' Co-Operative Publishing Company).

Maddison, Angus. "Historical Statistics for the World Economy: 1-2003 AD." www.ggdc.net/maddison/Historical_Statistics/horizontal-file_03-2007.xls, accessed March 2009.

McCune, Shannon. 1948. “Land Redistribution in Korea,” Far Eastern Survey 17(2): 13-18.

Miller, Hugo. 1920.Economic Conditions in the Philippines (New York: Ginn \& Co.).

Mitchener, Kris, and Marc Weidenmier. 2005. "Empire, Public Goods, and the Roosevelt Corollary.” Journal of Economic History 65: 658-92 
Myers, Ramon, and Yamada Saburo. 1984. “Agricultural Development in the Empire,” in Ramon Myers and Mark Peattie, eds, The Japanese Colonial Empire, 1895-1945 (Princeton: Princeton University Press).

Montero, José. El Archipiélago Filipino y las islas Marianas, Carolinas, y Palaos (Imprenta Manuel Tello, Madrid, 1886).

New York Times, various.

North, Douglass, and Robert Thomas. 1973. The Rise of the Western World: A New Economic History (Cambridge: Cambridge University Press).

Pilapil, Vicente. 1961. "Nineteenth-Century Philippines and the Friar-Problem,” The Americas 18(2): 127-148.

Russell, Charles. 1922. The Outlook for the Philippines (New York: Century Company).

SMERU Research Team. "An Impact Evaluation of Systematic Land Titling under the Land Administration Project (LAP).” Working paper.

Stanley, Peter. 1974. The Philippines and the United States, 1898-1921 (Cambridge: Harvard University Press).

Stanley, Peter. 1974. A Nation in the Making The Philippines and the United States, 1899-1921. (Cambridge: Harvard University Press).

Torres, Fabio Sanchez, Antonella Fazio Vargas and Maria del Pilar Lopez-Uribe. 2008. "Land Conflicts, Property Rights and the Rise of the Export Economy in Colombia 1850-1925.” Working paper.

Yager, Joseph. 1988. Transforming Agriculture in Taiwan: the Experience of the Joint Commission on Rural Reconstruction. (Ithaca and London: Cornell University Press). 
Table 1: Population densities, circa 1900

\begin{tabular}{lrrr}
\hline & Area $(\mathbf{k m 2})$ & $\begin{array}{l}\text { Population } \\
\mathbf{( 1 0 0 0 s )}\end{array}$ & $\begin{array}{l}\text { People per } \\
\text { hectare }\end{array}$ \\
\hline Philippines & 115,094 & 7,635 & 0.66 \\
Cebu & 5,088 & 651 & 1.28 \\
Leyte & 7,448 & 386 & 0.52 \\
Luzon & 40,410 & 3,405 & 0.84 \\
Mindoro & 10,245 & 39 & 0.04 \\
Negros & 13,328 & 507 & 0.38 \\
Panay & 11,693 & 771 & 0.66 \\
Samar & 13,429 & 265 & 0.20 \\
Indiana & 35,866 & 2,700 & 0.75 \\
Vietnam & 127,210 & 13,765 & 1.08 \\
Japan & 145,844 & 45,437 & 3.12 \\
Java & 48,906 & 30,098 & 6.15 \\
Korea & 218,600 & 9,896 & 4.53 \\
Taiwan & 32,260 & 2,864 & 8.88 \\
\hline
\end{tabular}

Sources: Land areas from the CIA World Fact Book.

Populations from the Encyclopedia Britannica of 1911.

Philippine provinces figures from census of 1903.

Korea and Taiwan populations from Maddison "Historical Statistics".

Table 2: Progress of friar land distribution

\begin{tabular}{cccccc}
\hline Year & $\begin{array}{c}\text { Contracted } \\
\text { income }\end{array}$ & $\begin{array}{c}\text { Amount in } \\
\text { delinquency }\end{array}$ & $\begin{array}{c}\text { Percent in } \\
\text { delinquency }\end{array}$ & $\begin{array}{c}\text { Delinquency } \\
\text { cases filed }\end{array}$ & Evictions \\
\hline & & & & & \\
1906 & 205,885 & 98,661 & $48 \%$ & & \\
1907 & 241,833 & & & & \\
1908 & 265,441 & & & & \\
1909 & 365,324 & 2,790 & $1 \%$ & 418 & 185 \\
1910 & 517,716 & 75,935 & $15 \%$ & 627 & 24 \\
1911 & $1,068,706$ & 185,984 & $17 \%$ & 634 & 42 \\
1912 & $1,124,477$ & 417,399 & $37 \%$ & 1,333 & 122 \\
1913 & $1,183,029$ & 124,985 & $11 \%$ & 5,472 & 160 \\
1914 & $1,185,188$ & 284,747 & $24 \%$ & 5,649 & 1,005 \\
1915 & $1,148,686$ & 284,492 & $25 \%$ & & \\
\hline
\end{tabular}

Sources: 1906 Philippine Commission report, part 2, p. 3, 1916 Philippine Commission report, p. 81, and 1915 Philippine Commission report, p. 81-83. 
Table 3: Progress of Torrens titling

\begin{tabular}{lccc}
\hline Year & Decrees & Parcels & \multicolumn{1}{c}{$\begin{array}{l}\text { Area (hec- } \\
\text { tares) }\end{array}$} \\
\hline 1903 & 126 & 140 & $\begin{array}{r}35 \\
1904\end{array}$ \\
1905 & 594 & 312 & 34,685 \\
1906 & 655 & 681 & 15,776 \\
1907 & 678 & 880 & 49,156 \\
1908 & 898 & 1,232 & 20,299 \\
1909 & 635 & 899 & 28,724 \\
1910 & 625 & 1,023 & 82,551 \\
1911 & 2,274 & 3,938 & 43,362 \\
1912 & 3,580 & 4,776 & 64,594 \\
1913 & 4,402 & 5,408 & 85,050 \\
1914 & 3,962 & 5,881 & 75,493 \\
1915 & 1,242 & 2,770 & 55,218 \\
1916 & 5,825 & 7,168 & 82,314 \\
1917 & 37,811 & 40,817 & 180,597 \\
1918 & 10,197 & 11,507 & 53,255 \\
& & & \\
TOTAL & 73,765 & 88,257 & 894,875 \\
\hline
\end{tabular}

Source: The Philippine Statistical Review, Vol 4, Nos. 1-2, First and Second Quarters, 1937, p 210. 
Table 4: The cost of formality

\section{Low estimate of titling costs}

Number of farms without any title

$1,141,353$

Low estimate of untitled farm value

$\$ 40,651,126$

Low estimate of non-Torrens farm value

$\$ 67,122,745$

Flat registration fees, low estimate ( $\$ 10$ per farm)

$\$ 11,413,530$

Proportional-to-value charges (1.1\% of farm value)

$\$ 447,162$

Total cost of titling untitled farms

$\$ 11,860,692$

$\%$ of central government revenue

$37 \%$

$\%$ of central government revenue, after direct subsidies to provinces

$\%$ of central government revenue, net of direct and indirect subsidies to provinces and the operating costs of commercial and industrial units

High estimate of titling costs

Number of farms without Torrens title

$1,884,591$

Low estimate of non-Torrens farm value

$\$ 67,122,745$

Flat registration fees, high estimate (\$25 per farm)

$\$ 18,845,910$

Proportional-to-value charges ( $1.1 \%$ of farm value)

$\$ 738,350$

Total cost of titling all non-Torrens farms

$\$ 19,584,260$

$\%$ of central government revenue

$61 \%$

$\%$ of central government revenue, after direct subsidies to provinces

$\%$ of central government revenue, net of direct and indirect subsidies to provinces and the operating costs of commercial and industrial units

Source: 1918 Census, Volume IV-2, p. 82, and 1918 Report of the Auditor for the Philippine Islands, p. 24. 
Table 5: Comparison of government revenues across countries, circa 1920 (US\$)

\begin{tabular}{|c|c|c|c|}
\hline & $\begin{array}{c}\text { Gov't revenue } \\
\text { per capita }\end{array}$ & $\begin{array}{l}\text { Gov't revenue } \\
\text { as a \% of GDP }\end{array}$ & $\begin{array}{c}\text { Nominal GDP } \\
\text { per capita }\end{array}$ \\
\hline Philippine Islands ${ }^{1}$ & $\$ 4$ & $10.5 \%$ & $\$ 36$ \\
\hline Puerto Rico & $\$ 15$ & $7.9 \%$ & $\$ 190$ \\
\hline United States $^{2}$ & $\$ 85$ & $10.6 \%$ & $\$ 803$ \\
\hline India $^{3}$ & & $6.0 \%$ & \\
\hline Malaya & $\$ 16$ & $9.0 \%$ & $\$ 181$ \\
\hline Korea & $\$ 4$ & $9.5 \%$ & $\$ 42$ \\
\hline Dutch East Indies & $\$ 5$ & $9.6 \%$ & $\$ 52$ \\
\hline Taiwan & $\$ 7$ & $10.5 \%$ & $\$ 64$ \\
\hline Burma $^{3}$ & $\$ 5$ & $11.7 \%$ & $\$ 43$ \\
\hline Vietnam & $\$ 3$ & $14.2 \%$ & $\$ 21$ \\
\hline Peru & $\$ 6$ & $3.4 \%$ & $\$ 163$ \\
\hline Mexico & $\$ 9$ & $5.1 \%$ & $\$ 176$ \\
\hline Argentina ${ }^{4}$ & $\$ 17$ & $3.9 \%$ & $\$ 444$ \\
\hline Cuba & $\$ 25$ & $6.6 \%$ & $\$ 375$ \\
\hline Brazil & $\$ 8$ & $11.3 \%$ & $\$ 69$ \\
\hline
\end{tabular}

Notes: (1) The P.I. figure is for 1918. It does not include the revenues of government corporations, which made up an additional 3\% of GDP. The figures for other countries include such revenues.

(2) The U.S. estimate is for 1922. It includes state and local governments.

(3) The denominator for the Burmese and Indian estimates is NNP, not GDP. Both figures are for 1921-22.

(4) The Argentine estimate does not include provincial governments.

Sources: Government revenues: Philippines, calculated from data in the 1918 Report of the Auditor for the Philippine Islands, p. 15. U.S., Historical Statistics of the United States, Millennial Edition, p. 5-10. All Asian colonies save India and Taiwan, Booth 2007, p. 248. Taiwan, Ho 1975, Table 7. All Latin American states save Mexico and Argentina, the Oxford Latin American Studies Database. Mexico, calculated from data in Haber, Maurer, and Razo 2003, Table 5. Argentine data provided by Leticia Arroyo Abad. India, Kumar 1982, p. 926.

Nominal GDP: Philippines, authors' calculations, following the methodology in Hooley 2005 with data from the 1918 census. United States, eh.net. All Asian colonies save India and Burma, calculated from data in Bassino and Van der Eng, 2005, Tables 2 and 3. Burma, Booth 2007, p. 258. All Latin American states, the Oxford Latin American Studies Database. 
Table 6: U.S. War Department spending in the Philippines

\begin{tabular}{rrc}
\hline & $\begin{array}{c}\text { Military-related } \\
\text { expenditures }\end{array}$ & $\begin{array}{c}\text { Percent of } \\
\text { Philippine GDP }\end{array}$ \\
\hline 1902 & $\$ 13,443,617$ & $7.7 \%$ \\
1903 & $\$ 15,787,605$ & $7.2 \%$ \\
1904 & $\$ 8,949,872$ & $4.8 \%$ \\
1905 & $\$ 9,603,208$ & $4.8 \%$ \\
1906 & $\$ 9,871,070$ & $4.7 \%$ \\
1907 & $\$ 9,254,317$ & $4.2 \%$ \\
1908 & $\$ 8,544,315$ & $3.6 \%$ \\
1909 & $\$ 9,744,517$ & $4.0 \%$ \\
1910 & $\$ 10,417,080$ & $3.6 \%$ \\
1911 & $\$ 9,330,310$ & $2.9 \%$ \\
1912 & $\$ 9,499,608$ & $2.9 \%$ \\
1913 & $\$ 9,176,125$ & $2.5 \%$ \\
1914 & $\$ 8,833,218$ & $2.5 \%$ \\
1915 & $\$ 11,220,182$ & $3.5 \%$ \\
1916 & $\$ 15,994,112$ & $4.0 \%$ \\
& & \\
\hline
\end{tabular}

Sources: 1903-14 from Elliott, Appendix J, pp. 523-525. 1899-1902 calculated from data in "Army's Cost in Philippines," New York Times, 11/11/11. 1915-16 calculated from data in Malcolm, p. 236. 
Table 7: What affected the expansion of the agricultural frontier?

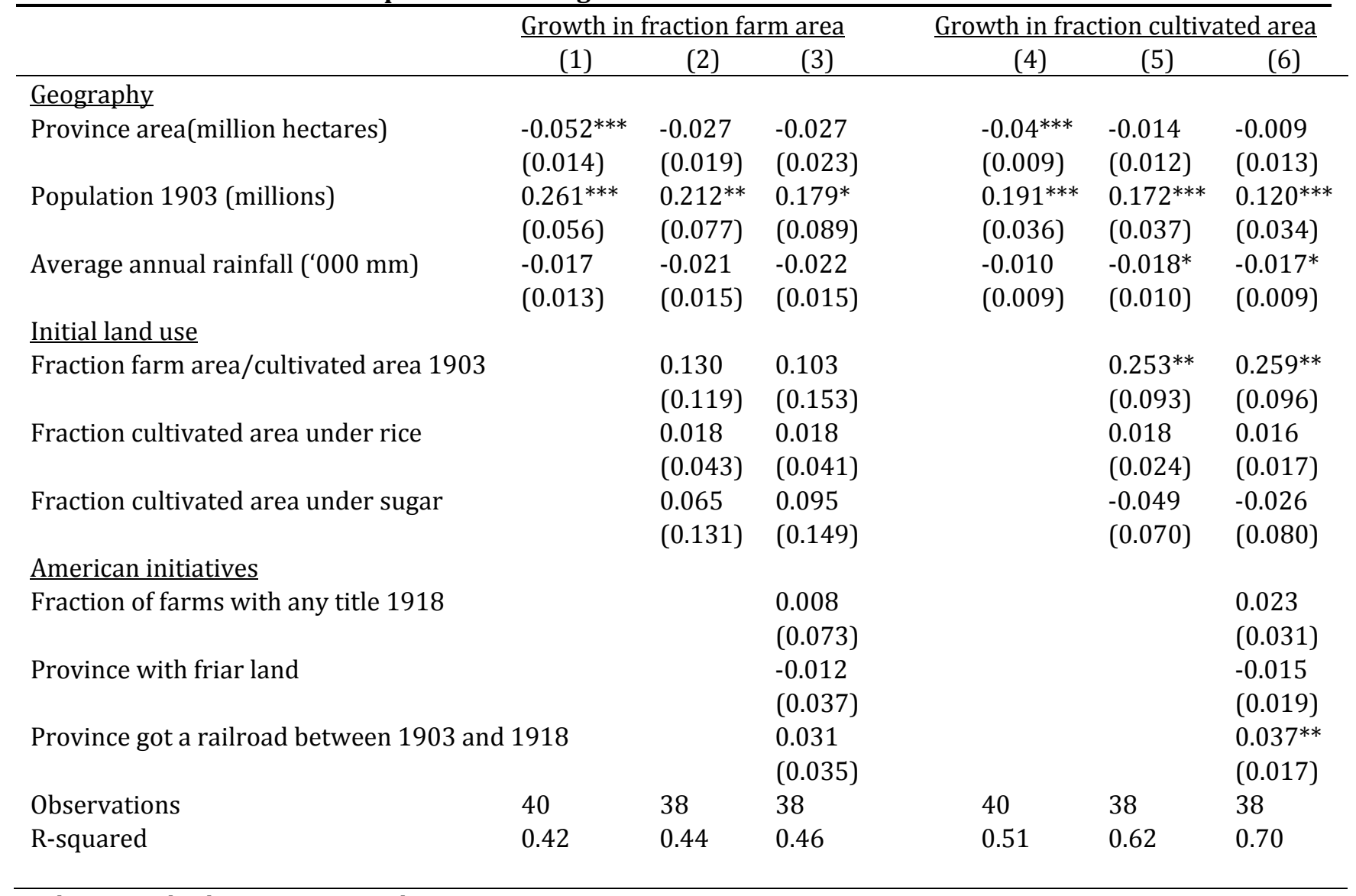

Robust standard errors in parentheses

$* 1 \%$ significant at $10 \%$, ** significant at $5 \%$; *** significant at $1 \%$

All regressions exclude the province of Manila City.

Table 8: Proportion of farms and cultivated area under different ownership categories

\begin{tabular}{lrrrrr} 
& \multicolumn{2}{c}{ Fraction of farms } & & \multicolumn{2}{c}{ Fraction of cultivated area } \\
\cline { 2 - 5 } & 1903 & 1918 & & 1903 & 1918 \\
\hline Owners & $80.8 \%$ & $77.7 \%$ & & $74.1 \%$ & $74.0 \%$ \\
Cash tenants & $1.8 \%$ & $3.2 \%$ & & $4.5 \%$ & $4.8 \%$ \\
Share tenants & $16.2 \%$ & $13.1 \%$ & & $19.0 \%$ & $13.3 \%$ \\
Labor tenants & $0.2 \%$ & $0.3 \%$ & $0.0 \%$ & $0.4 \%$ \\
No rental (squatters) & $1.1 \%$ & $5.7 \%$ & $2.4 \%$ & $7.5 \%$ \\
\hline
\end{tabular}

Source: Authors' calculations from the censuses of 1903 and 1918 
Table 9: What determined squatting?

\begin{tabular}{|c|c|c|c|c|c|c|}
\hline & \multicolumn{3}{|c|}{ Change in \% cult area under squatters } & \multicolumn{3}{|c|}{ Change in \% farms under squatters } \\
\hline & (1) & (2) & (3) & (4) & (5) & (6) \\
\hline $\begin{array}{l}\text { Growth in fraction cultivated } \\
\text { area }\end{array}$ & $\begin{array}{l}-0.636^{* *} \\
(0.268)\end{array}$ & $\begin{array}{l}-0.138 \\
(0.147)\end{array}$ & $\begin{array}{l}-0.099 \\
(0.176)\end{array}$ & $\begin{array}{l}-0.560^{*} \\
(0.294)\end{array}$ & $\begin{array}{l}-0.202 \\
(0.140)\end{array}$ & $\begin{array}{l}-0.137 \\
(0.223)\end{array}$ \\
\hline Province area(million hectares) & $\begin{array}{l}-0.010 \\
(0.031)\end{array}$ & $\begin{array}{l}-0.013 \\
(0.022)\end{array}$ & $\begin{array}{l}-0.016 \\
(0.025)\end{array}$ & $\begin{array}{l}0.008 \\
(0.054)\end{array}$ & $\begin{array}{l}-0.058 \\
(0.045)\end{array}$ & $\begin{array}{l}-0.056 \\
(0.045)\end{array}$ \\
\hline $\begin{array}{l}\text { Proxies for risk of eviction } \\
\text { Change in population density pel }\end{array}$ & & & & & & \\
\hline 10000 ha cultivated area) & & $\begin{array}{l}-0.366 \\
(0.335)\end{array}$ & $\begin{array}{l}-0.367 \\
(0.347)\end{array}$ & & $\begin{array}{l}0.451 \\
(0.713)\end{array}$ & $\begin{array}{l}0.505 \\
(0.690)\end{array}$ \\
\hline Fraction of farms on public land & & $\begin{array}{l}0.577^{* * *} \\
(0.087)\end{array}$ & $\begin{array}{l}0.551^{* * *} \\
(0.075)\end{array}$ & & $\begin{array}{l}0.772^{* * *} \\
(0.193)\end{array}$ & $\begin{array}{l}0.775^{* * *} \\
(0.177)\end{array}$ \\
\hline $\begin{array}{l}\text { Value of land stolen/total prop- } \\
\text { erty value }(* 100,000)\end{array}$ & & $\begin{array}{l}0.000 \\
(0.001)\end{array}$ & $\begin{array}{l}0.001 \\
(0.001)\end{array}$ & & $\begin{array}{l}0.001 \\
(0.001)\end{array}$ & $\begin{array}{l}0.001 \\
(0.001)\end{array}$ \\
\hline $\begin{array}{l}\text { Fraction of farms with any title } \\
1918\end{array}$ & & $\begin{array}{l}-0.060 \\
(0.052)\end{array}$ & $\begin{array}{l}-0.090 \\
(0.057)\end{array}$ & & $\begin{array}{l}-0.038 \\
(0.072)\end{array}$ & $\begin{array}{l}-0.082 \\
(0.072)\end{array}$ \\
\hline Proxies for cost of formalization & & & & & & \\
\hline Daily agricultural wage 1918 & & & $\begin{array}{l}-0.017 \\
(0.075)\end{array}$ & & & $\begin{array}{l}-0.058 \\
(0.096)\end{array}$ \\
\hline $\begin{array}{l}\text { Property tax per hectare of cul- } \\
\text { tivated area }\end{array}$ & & & $\begin{array}{l}0.045 \\
(0.030)\end{array}$ & & & $\begin{array}{l}0.076 \\
(0.070)\end{array}$ \\
\hline Observations & 40 & 39 & 35 & 41 & 40 & 36 \\
\hline R-squared & 0.14 & 0.65 & 0.71 & 0.07 & 0.59 & 0.63 \\
\hline
\end{tabular}

Robust standard errors in parentheses

${ }^{*} 1 \%$ significant at $10 \%,{ }^{* *}$ significant at $5 \%$; ${ }^{* *}$ significant at $1 \%$

All regressions exclude the province of Manila City. 
Table 10: What determined changes in inequality?

\begin{tabular}{lccc}
\hline & $\begin{array}{c}\text { Change in } \\
\text { cultivated } \\
\text { area Gini } \\
(1)\end{array}$ & $\begin{array}{c}\text { Change in \% culti- } \\
\text { vated area in large } \\
\text { farms } \\
(2)\end{array}$ & $\begin{array}{c}\text { Change in \% culti- } \\
\text { vated area in } \\
\text { small farms } \\
(3)\end{array}$ \\
\hline Growth in fraction cultivated & 1.053 & $1.525^{*}$ & -0.617 \\
area & $(0.749)$ & $(0.824)$ & $(0.622)$ \\
Province with friar land & 0.005 & -0.049 & 0.018 \\
& $(0.043)$ & $(0.063)$ & $0.046)$ \\
Fraction of farms with any title & -0.030 & -0.041 & -0.070 \\
1918 & $(0.106)$ & $(0.150)$ & $0.153)$ \\
Change in \% cult area under & 0.271 & 0.382 & -0.381 \\
squatters & $(0.294)$ & $(0.354)$ & $0.415)$ \\
Change in Population density & -0.282 & -0.650 & 0.207 \\
& $(0.417)$ & $(0.424)$ & $0.311)$ \\
Observations & & & 40 \\
R-squared & 40 & 40 & 0.07 \\
& 0.11 & 0.20 & \\
\hline
\end{tabular}

Robust standard errors in parentheses

${ }^{*} 1 \%$ significant at $10 \%$, ${ }^{* *}$ significant at $5 \%$; ${ }^{* * *}$ significant at $1 \%$ All regressions exclude the province of Manila City. 
Appendix 1: Summary statistics for province level variables

\begin{tabular}{lrrrrr}
\hline & $\begin{array}{c}\text { Obser- } \\
\text { vations }\end{array}$ & Mean & S.D. & $\begin{array}{r}\text { Mini- } \\
\text { mum }\end{array}$ & Maximum \\
\hline & & & & & \\
Province area (million hectares) & 41 & 0.72 & 0.61 & 0.09 & 2.49 \\
Population 1903 (millions) & 41 & 0.18 & 0.12 & 0.04 & 0.65 \\
Population 1918 (millions) & 41 & 0.24 & 0.16 & 0.04 & 0.86 \\
Fraction farm area 1903 & 41 & 0.17 & 0.14 & 0.00 & 0.48 \\
Fraction farm area 1918 & 41 & 0.26 & 0.20 & 0.01 & 0.73 \\
Fraction cultivated area 1903 & 41 & 0.09 & 0.09 & 0.00 & 0.35 \\
Fraction cultivated area 1918 & 41 & 0.15 & 0.13 & 0.00 & 0.50 \\
Friar land dummy & 41 & 0.20 & 0.40 & 0.00 & 1.00 \\
Fraction of farms on public land & 41 & 0.08 & 0.13 & 0.00 & 0.64 \\
Fraction of farms with any title 1918 & 41 & 0.38 & 0.20 & 0.00 & 0.77 \\
Property tax per hectare of cultivated area & 41 & 1.09 & 0.81 & 0.23 & 5.44 \\
Growth in fraction farm area & 41 & 0.09 & 0.08 & -0.03 & 0.25 \\
Growth in fraction cultivated area & 41 & 0.06 & 0.05 & 0.00 & 0.19 \\
Fraction of cult. area devoted to cash crops, & & & & & \\
1918 & 41 & 0.05 & 0.06 & 0.00 & 0.27 \\
Change in \% cultivated area under squatters & 40 & 0.07 & 0.09 & -0.10 & 0.35 \\
Daily agricultural wage 1918 & 38 & 0.64 & 0.18 & 0.30 & 1.15 \\
Province had a railroad 1903 & 41 & 0.12 & 0.33 & 0 & 1 \\
Province had a railroad 1918 & 41 & 0.37 & 0.49 & 0 & 1 \\
Fraction of cultivated area devoted to rice 1903 & 39 & 0.49 & 0.30 & 0.03 & 1 \\
Fraction of cult. area devoted to sugar 1903 & 41 & 0.04 & 0.07 & 0 & 0.38 \\
Change in \% cultivated area devoted to sugar & 41 & 0.01 & 0.06 & -0.11 & 0.28 \\
Average annual rainfall 1903-1918 (mm) & 40 & 2297 & 652 & 1186 & 4598 \\
Fraction of farms irrigated 1918 & 41 & 0.22 & 0.16 & 0 & 0.57 \\
Carabaos per hectare 1903 & 41 & 0.73 & 0.72 & 0.07 & 3.59 \\
Carabaos per hectare 1918 & 41 & 0.63 & 0.43 & 0.11 & 1.84 \\
Farm credit per hectare of cultivated land 1918 & 35 & 0.16 & 0.25 & 0 & 1.11 \\
& & & & & \\
\hline
\end{tabular}

Source: $\quad$ Authors' calculations based on province-level data from the censuses of 1903 and 1918. 
Figure 1a: Lorenz curves for cultivated land, all provinces

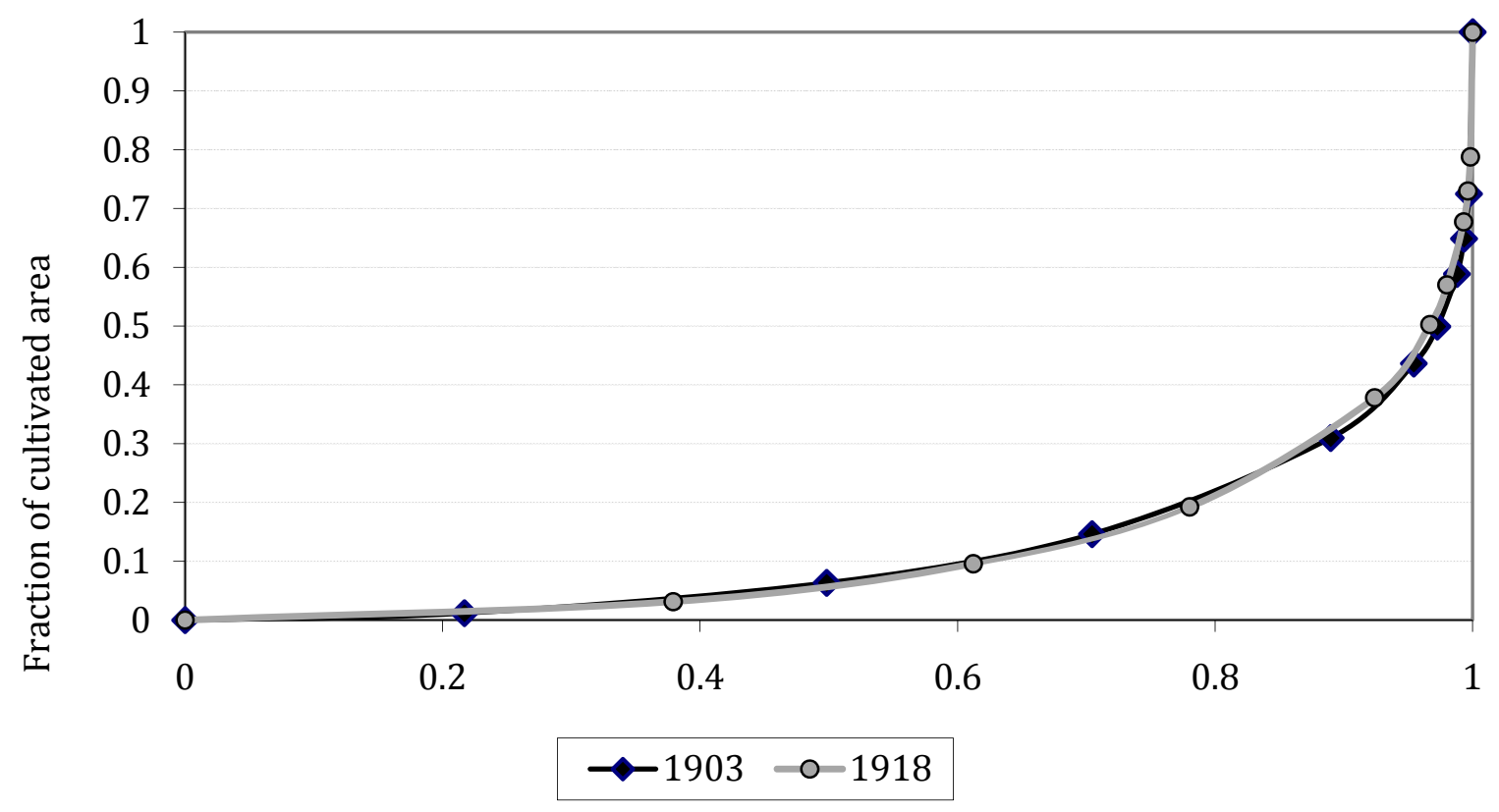

Figure 1b: Lorenz curves for cultivated land, friar land provinces only

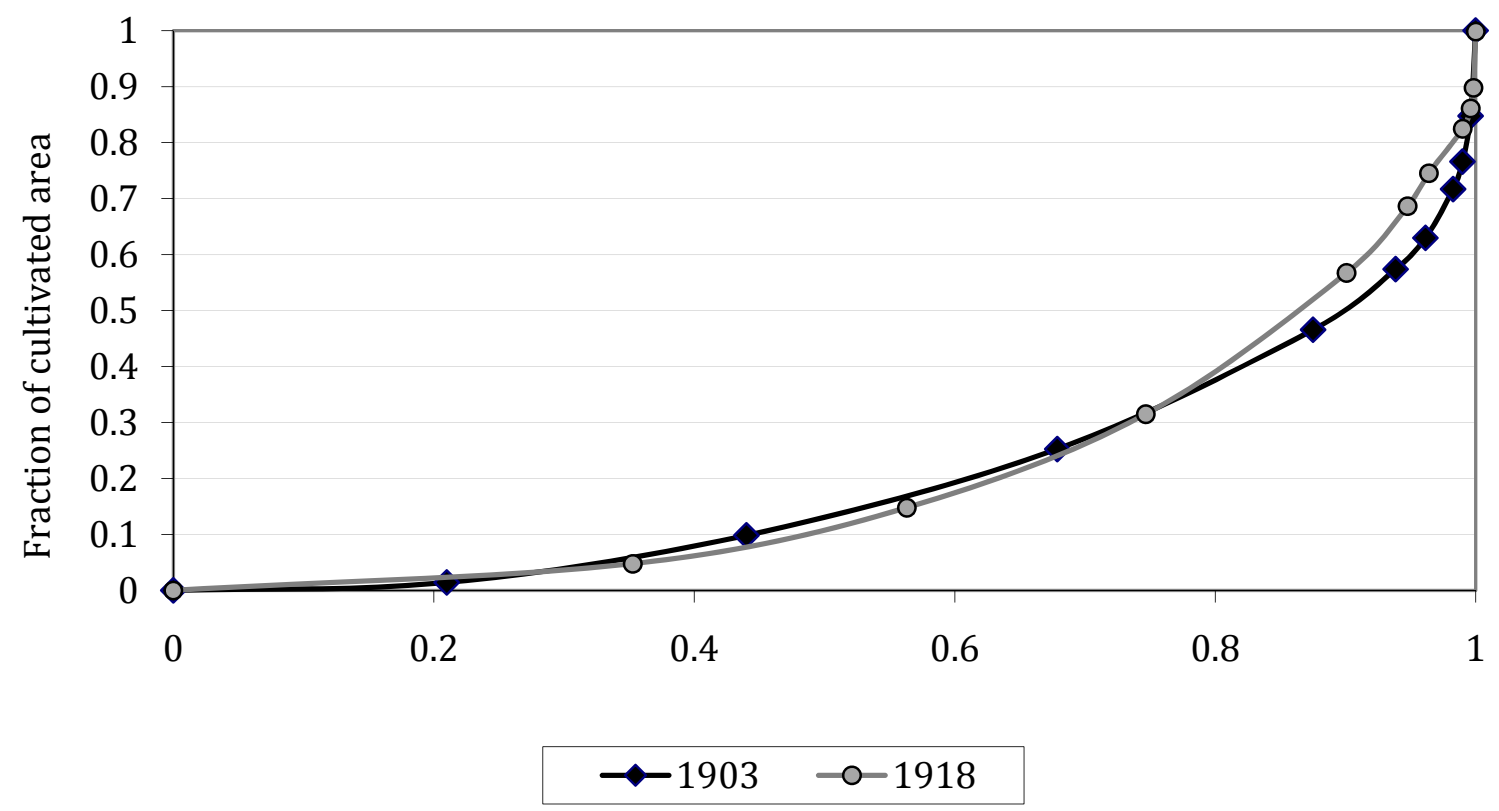


Figure 2

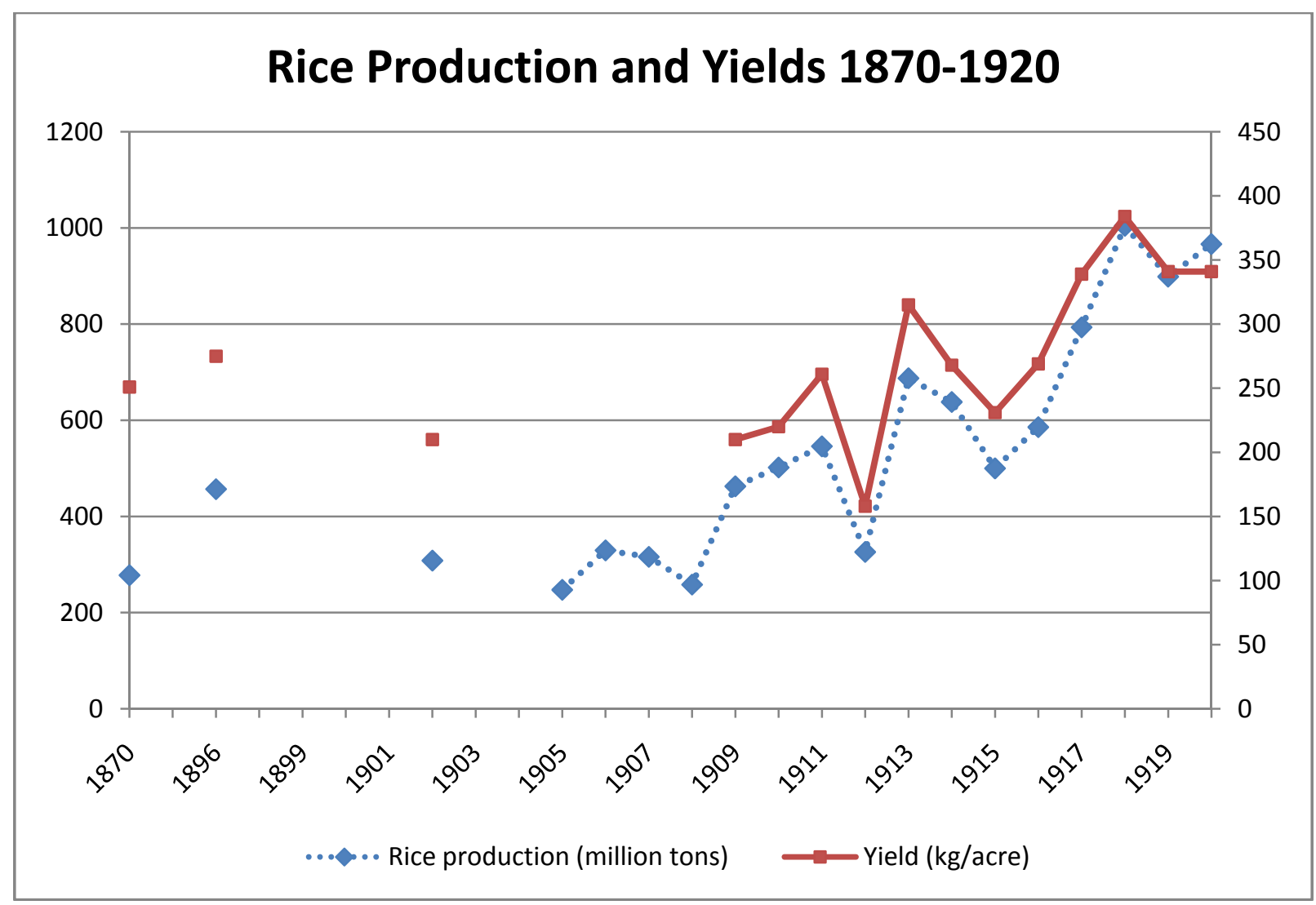

1870 production data calculated fromprovincial-level data from the Spanish economic census of 1870 published in José Montero, El Archipiélago Filipino y las islas Marianas, Carolinas, y Palaos (Imprenta Manuel Tello, Madrid, 1886), pp. 324-426. 1870 acreage data from Agustín de la Cavada, Historia Geografica, Geologica y Estadistica de Filipinas, Manila, 1876, pp. 346-47. (Cavada's data also came from the 1870 economic census.) 1896 acreage data from James Leroy, Philippine Life in Town and Country (New York, G. P. Putnam's Sons, 1905), p. 273. 1896 production data from 1901 Report of the Philippine Commission, Volume 4, p. 11. (Volume 4 I sunclear as to the provenance of the data, but Volume 2, pp. 578-80 discuss the partial agricultural schedules to the 1896 Spanish census manuscripts, from which Leroy derived his estimates of cultivated land.) 1902-20 production and acreage data from USDA, 1908 Yearbook of Agriculture, p. 693; USDA, 1912 Yearbook of the U.S. Department of Agriculture, pp. 63839; USDA, 1919 Yearbook of the U.S. Department of Agriculture, p. 503; and USDA, 1921 Yearbook of Agriculture, p. 576. 
Figure 3: Philippine provincial map

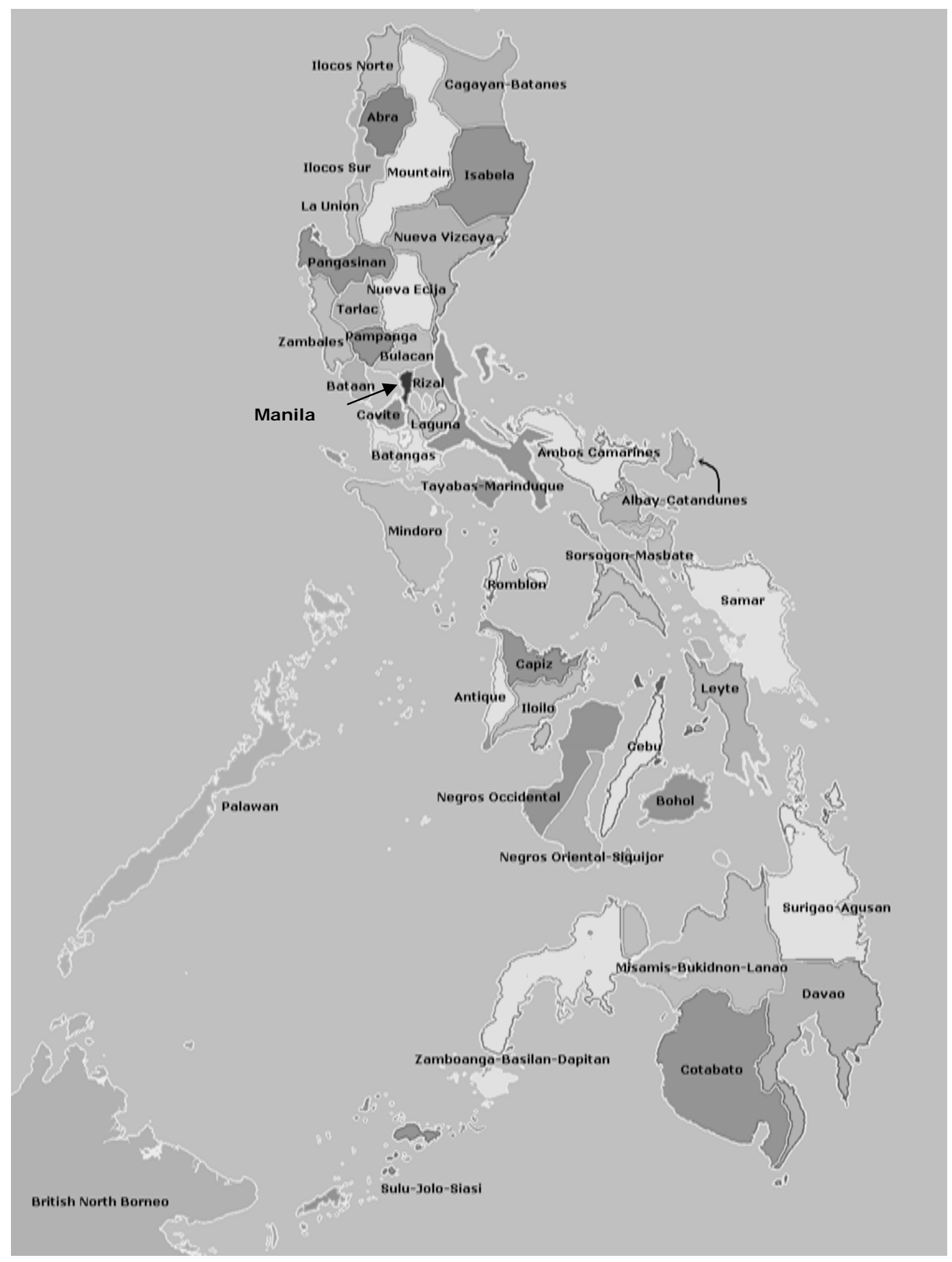

